\title{
Porezni klin u Hrvatskoj, Belgiji, Estoniji, Njemačkoj i Slovačkoj
}

\section{Gabrilo, Ana}

Source / Izvornik: Odabrani prijevodi, 2016, 7, 1 - 35

Journal article, Published version

Rad u časopisu, Objavljena verzija rada (izdavačev PDF)

https://doi.org/10.3326/op.40

Permanent link / Trajna poveznica: https:/urn.nsk.hr/urn:nbn:hr:242:038392

Rights / Prava: Attribution-NonCommercial-NoDerivatives 4.0 International/ImenovanjeNekomercijalno-Bez prerada 4.0 međunarodna

Download date / Datum preuzimanja: 2023-04-26

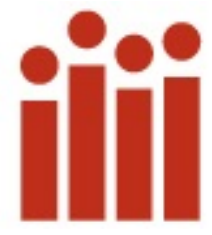

Institute of Public Finance Repository

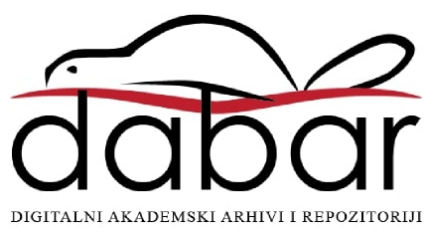


Institut za

javne financije

Smičiklasova 21 | Zagreb

www.ijf.hr | ured@ijf.hr

T: 01/4886-444 | F: 01/4819-365

\section{ODABRANI}

\section{PRIJEVODI}

\section{BR. 40}

\section{6.}

ISSN 1847-7445

citirati: Gabrilo, A., 2016. Tax wedge in Croatia, Belgium, Estonia, Germany and Slovakia. Financial Theory and Practice, 40 (2), str. 231-264. Dostupno na: $<$ http://www.fintp.hr/upload/files/ftp/ 2016/2/gabrilo.pdf>.

Svi Odabrani prijevodi dostupni su na: http://www.ijf.hr/hr/publikacije/casopi si/12/odabrani-prijevodi/111/

\section{Porezni klin u HrVatskoJ, BelgiJi, EstoniJi, NJEMAČKOJ I SLOVAČKOJ}

MAG. MATH ANA GABRILO*

\author{
PRETHODNO PRIOPĆENJE* \\ JEL: H21, H24, J38 \\ DOI: $10.3326 /$ op.40
}

\section{SAŽETAK}

Cilj rada je proučiti oporezivanje dohotka od rada u Hrvatskoj, Belgiji, Estoniji, Njemačkoj i Slovačkoj. Nakon pregleda pravila poreznih sustava, prikazana je dekompozicija neto prosječnog poreznog klina za različite tipove obitelji i razine dohotka, koristeći OECD-ovu metodologiju. Dobiveni rezultati ukazuju na progresivnost oporezivanja u svim promatranim zemljama, osim Njemačke gdje progresivnost izostaje za više razine bruto plaće, a posljedica je najviše osnovice doprinosa za socijalno osiguranje. $\mathrm{Na}$ razini prosječne bruto plaće najmanje porezno opterećenje za samce bez djece je u Hrvatskoj, a slijede Estonija, Slovačka, Njemačka i Belgija. Međutim, na razini 400\% prosječne bruto plaće, najmanji porezni klin je u Estoniji, a slijede Slovačka, Njemačka i Hrvatska te Belgija. Slične rezultate pokazuje i analiza za par s dvoje djece u kojemu jedan supružnik ne radi.

Ključne riječi: oporezivanje dohotka od rada, progresivnost, porezni klin, Belgija, Estonija, Njemačka, Slovačka, Hrvatska

\footnotetext{
* Autorica zahvaljuje anonimnim recenzentima na njihovim korisnim komentarima i prijedlozima. Ovaj članak je dio posebnog izdanja časopisa Financial Theory and Practice, posvećenom usporedbi poreznog klina na dohodak od rada u Hrvatskoj i drugim zemljama EU-a. Članci u tom izdanju su nastali na temelju studentskog istraživačkog projekta poduzetog 2015. Predgovor posebnom izdanju (Urban, 2016.) opisuje motivaciju istraživačkog projekta, objašnjava najvažnija metodološka pitanja te pruža pregled literature o mjerenju poreznog klina u Hrvatskoj.

** Primljeno: 8. veljače 2016.

Prihvaćeno: 6. travnja 2016.
}

\section{Ana GABRILO}

Deloitte d.o.o., Radnička cesta 80, 10000 Zagreb

e-mail: ana.gabrilo5@gmail.com 


\section{UvoD}

Porezni sustav neke zemlje te način oporezivanja dohotka od rada, kao segment poreznog sustava, su važni elementi koji utječu na konkurentnost na međunarodnom tržištu, posebno na tržištu rada. Predmet analize ovog rada je porezno opterećenje dohotka od rada u Hrvatskoj, Belgiji, Estoniji, Njemačkoj i Slovačkoj u 2013. Rad predstavlja dio rezultata istraživanja poreznog opterećenja u Hrvatskoj i zemljama EU-a (vidjeti Urban, 2016.).

Kako bi se izračunali pokazatelji poreznog opterećenja, izrađen je mikrosimulacijski model koji za hipotetske jedinice (samce i obitelji) u svakoj od odabranih zemalja izračunava iznose doprinosa za socijalno osiguranje, poreza na dohodak i novčanih naknada za djecu. Dekompozicija neto prosječnog poreznog klina pokazuje kako različiti elementi poreznog sustava djeluju na progresivnost ukupnog sustava i poreznom opterećenju različitih tipova obitelji.

Rad je podijeljen u četiri dijela. Nakon uvoda, u drugom dijelu su prikazane metodološke pretpostavke te su definirani osnovni pojmovi. Treći dio prikazuje rezultate izračuna neto prosječnog poreznog klina i njegovih sastavnica. U četvrtom poglavlju uspoređuju se rezultati među zemljama. Posljednji dio je zaključak. Pregled pravila i obilježja oporezivanja dohotka od rada u odabranim zemljama nalazi se u dodatku.

\section{Metodologija}

U svrhu računanja pokazatelja poreznog opterećenja te ostalih varijabli potrebnih za njihov izračun, u ovom radu koristi se metodologija u skladu s OECD-ovom publikacijom Taxing Wages (OECD, 2014.). Svi izračuni odnose se na 2013. Tablica 1 prikazuje osam osnovnih hipotetskih jedinica za koje se izračunavaju pokazatelji poreznog opterećenja.

\section{TABLICA 1.}

Obilježja promatranih hipotetskih jedinica

\begin{tabular}{lcccc}
$\begin{array}{l}\text { Oznaka u } \\
\text { ovom radu }\end{array}$ & Odrasli članovi & Broj djece & $\begin{array}{c}\text { Supružnik I } \\
\text { (\% AGW-a) }\end{array}$ & $\begin{array}{c}\text { Supružnik II } \\
\text { (\% AGW-a) }\end{array}$ \\
\hline 1A-67-NC & samac & 0 & $2 / 3 \times 100$ & - \\
\hline $1 \mathrm{~A}-100-\mathrm{NC}$ & samac & 0 & 100 & - \\
\hline $1 \mathrm{~A}-167-\mathrm{NC}$ & samac & 0 & $5 / 3 \times 100$ & - \\
\hline $1 \mathrm{~A}-67-2 \mathrm{C}$ & samac & 2 & $2 / 3 \times 100$ & - \\
\hline $2 \mathrm{~A}-100 / 0-2 \mathrm{C}$ & par & 2 & 100 & ne radi \\
\hline $2 \mathrm{~A}-100 / 33-2 \mathrm{C}$ & par & 2 & 100 & $1 / 3 \times 100$ \\
\hline $2 \mathrm{~A}-100 / 67-2 \mathrm{C}$ & par & 2 & 100 & $2 / 3 \times 100$ \\
\hline $2 \mathrm{~A}-100 / 33-\mathrm{NC}$ & par & 0 & 100 & $1 / 3 \times 100$ \\
\hline
\end{tabular}

Napomena: kratice su zasnovane na engleskom jeziku. Značenje pojedinih simbola je sljedeće: AGW - average gross wage (prosječna bruto plaća); $A$ - adult (odrasla osoba); $N C$ - no children (bez djece); $2 C$ - 2 children (dvoje djece).

Izvor: OECD (2014.).

Osim osam osnovnih hipotetskih jedinica, u radu se koriste još dva skupa hipotetskih jedinica. Prvi skup čine samci bez djece, čija se bruto plaća kreće u rasponu od 50 do 400\% AGW-a. Drugi skup čine parovi s dvoje djece, u kojima jedan supružnik ne radi, a plaća drugoga se kreće u rasponu od 50 ili 400\% AGW-a. Jedna od pretpostavki modela je da sve hipotetske jedinice ostvaruju jedino dohodak od rada (bruto plaća), a zarađuju ga odrasli članovi. Kako prikazuje Tablica 1, bruto plaće 
hipotetskih jedinica definirane su u odnosu spram prosječne bruto plaće (average gross wage; AGW) u svakoj zemlji. Izračun AGW-a se provodi u skladu s OECD (2014.). Tablica 2 prikazuje vrijednosti AGW-a za odabrane zemlje.

\section{TABLICA 2.}

Godišnje prosječne bruto plaće u odabranim zemljama, 2013.

\begin{tabular}{lccc} 
& AGW u nacionalnoj valuti & Tečaj & AGW (u eurima) \\
\hline Hrvatska & HRK 93.180 & HRK/EUR $=7,5735$ & 12.303 \\
\hline Belgija & EUR 46.810 & 1 & 46.810 \\
\hline Estonija & EUR 11.664 & 1 & 11.664 \\
\hline Njemačka & EUR 45.170 & 1 & 45.170 \\
\hline Slovačka & EUR 10.015 & 1 & 10.015 \\
\hline
\end{tabular}

Izvor: (1) AGW - za Hrvatsku: autoričin izračun prema DZS (2016.) i Urban (2016.); za ostale zemlje: OECD (2014.); (2) tečaj za Hrvatsku: HNB (2016.).

Porezi na dohodak plaćaju se središnjoj državnoj vlasti, a u nekim zemljama i jedinicama lokalne državne vlasti. Sukladno OECD-u (2014.), ukupni trošak rada definira se kao zbroj bruto plaće, poreza na platnu listu i doprinose poslodavca. Ukupno porezno opterećenje definira se kao zbroj poreza na platnu listu, doprinosa posloprimca, doprinosa poslodavca te poreza na dohodak, umanjeno za iznos novčanih naknada za obitelj. Neto prosječni porezni klin je omjer ukupnog poreznog opterećenja i ukupnog troška rada. Porezno opterećenje posloprimca definira se kao zbroj doprinosa posloprimca i poreza na dohodak, umanjen za novčane naknade za obitelj. Neto prosječna porezna stopa predstavlja udio poreznog opterećenja posloprimca u bruto plaći.

Važno je naglasiti da se pod doprinose posloprimca i poslodavca uzimaju u obzir samo doprinosi koji se plaćaju općoj državi, dok su doprinosi uplaćeni u fondove izvan opće države isključeni iz analize. Primjerice, u Hrvatskoj postoje dva stupa mirovinskog osiguranja - prvi i drugi stup. Doprinosi posloprimca u prvi stup su prihodi opće države, a doprinosi za drugi stup su prihodi obveznih privatnih fondova. Stoga će prvi ući u izračun pokazatelja poreznog opterećenja, a drugi neće. O ovoj temi opširnije vidjeti u Urban (2016.), Blažić i Trošelj (2012), OECD (2014., 2015.).

Progresivnost poreznog tereta se ogleda u povećanju neto prosječnog poreznog klina (neto prosječne porezne stope) s rastom bruto plaće. Progresivnost ukupnog sustava ovisi o interakciji njegovih elemenata - doprinosa za socijalno osiguranje, poreza na dohodak i novčanih naknada za obitelj. Svaki od ovih elemenata ima svoje specifičnosti. Doprinosi za socijalno osiguranje uglavnom su jednostopni i stoga bi trebali biti neutralni u odnosu na prosječne stope, ali najviše osnovice doprinosa mogu djelovati regresivno.

Progresivnost poreza na dohodak ovisi o broju i širini poreznih razreda te razlikama među graničnim poreznim stopama, osobito između najviše i najniže. Nadalje, progresivnost poreza na dohodak također ovisi o olakšicama, koje mogu umanjivati poreznu osnovicu (osobni odbici) ili poreznu obavezu (umanjenje poreza). Od odabranih zemalja, umanjenja porezne osnovice postoje u Estoniji, Slovačkoj i Hrvatskoj, a umanjenja porezne obaveze u Belgiji, Njemačkoj i Slovačkoj. Uobičajeno porezne olakšice djeluju progresivno, osim kod olakšica koje se dodjeljuju tako da relativno veće iznose ostvaruju osobe s većim dohotkom. 
Također, osobe i obitelji mogu biti korisnici različitih novčanih naknada za djecu. Ciljane skupine za takve naknade obično su kućanstva s nižom razinom dohotka, ali postoje i naknade bez provjere dohodovnog stanja, koje se u jednakim iznosima po djetetu daju svim kućanstvima. U oba slučaja te naknade djeluju progresivno jer smanjuju relativni porezni teret.

Dekompozicije poreznog opterećenja u trećem dijelu rada ilustrirat će za svaku odabranu zemlju kako različiti elementi sustava djeluju na progresivnost za različite hipotetske jedinice.

\section{Pokazatelji POREZnog OPTEREĆENJA PO ZEMLjAMa}

\subsection{HRVATSKA}

Opis sustava oporezivanja dohotka od rada za Hrvatsku nalazi se u dodatku A1.

Grafikon 1 prikazuje neto prosječni porezni klin i njegovu dekompoziciju za osnovne hipotetske jedinice - samce. Udio doprinosa u troškovima rada identičan je za sve razine bruto plaće, što je posljedica jedinstvenih stopa doprinosa i nepostojanja najviših osnovica za doprinose. ${ }^{1}$ Skupno gledajući, doprinosi poslodavca i posloprimca čine $26,2 \%$ ukupnog troška rada. Samac s dvoje djece i bruto plaćom od 67\% AGW-a (1A-67-2C) ne plaća porez na dohodak zahvaljujući relativno visokom osobnom odbitku. Progresivnost poreza na dohodak uočava se usporedbom njegovih udjela za hipotetske jedinice 1A-67-NC, 1A-100-NC i 1A-167-NC.

\section{GRAFIKON 1.}

Dekompozicija neto prosječnog poreznog klina za osnovne hipotetske jedinice: samce (Hrvatska 2013.), u \%

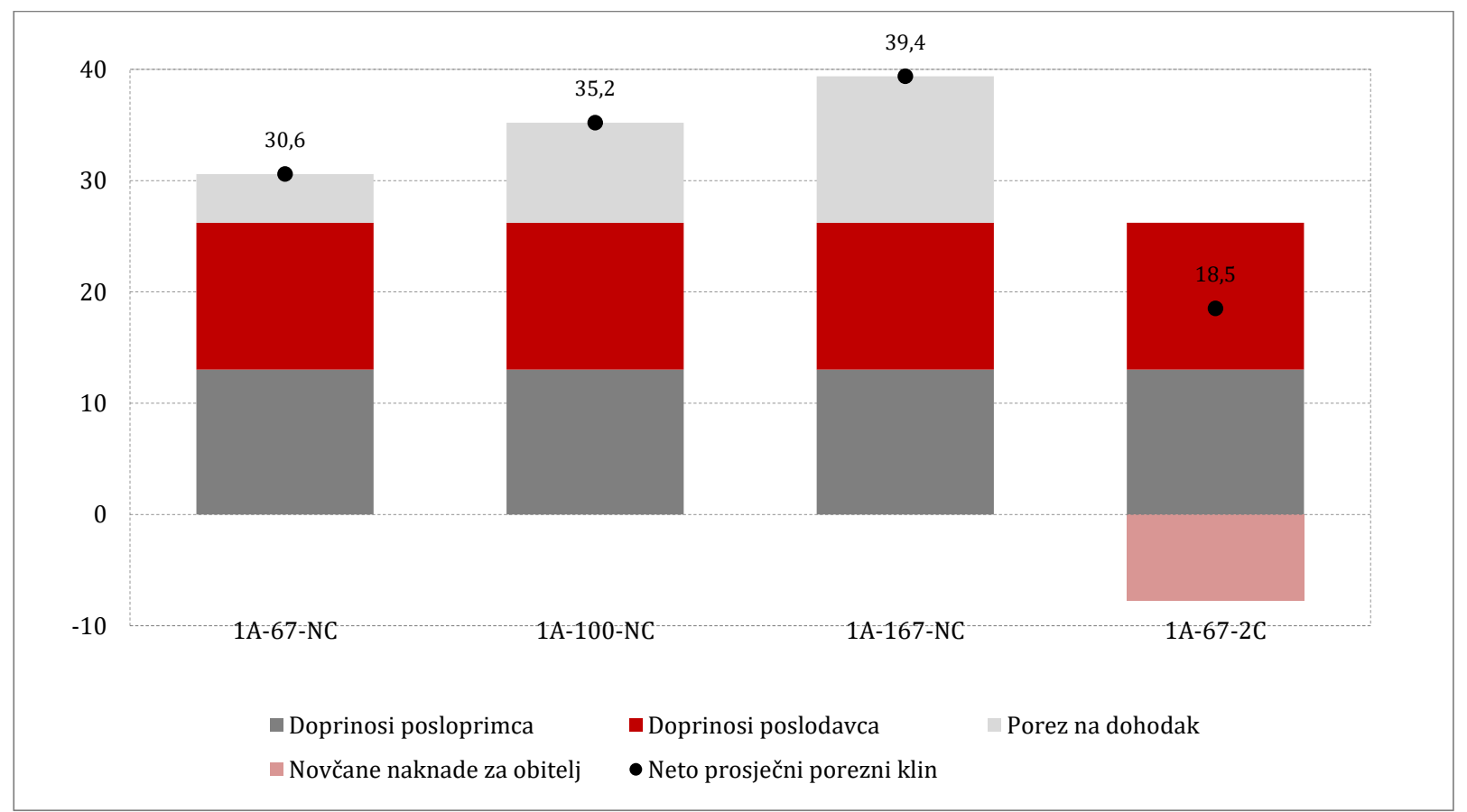

Napomena: stavka "Porez na dohodak" obuhvaća porez na dohodak i lokalni prirez. Izvor: autoričini izračuni.

\footnotetext{
${ }^{1}$ Najviša osnovica primjenjuje se jedino kod doprinosa za prvi stup mirovinskog osiguranja, ali ona nastupa tek pri razini od $600 \%$ prosječne bruto plaće (vidjeti dodatak A1).
} 
Grafikon 2 prikazuje dekompoziciju neto prosječnog poreznog klina za osnovne hipotetske jedinice - parove. Doprinosi za socijalno osiguranje imaju jednake udjele u ukupnom trošku rada kao kod samaca. Udio poreza na dohodak varira ovisno o razini dohotka i odbitku na osnovu uzdržavane djece. Znatno je manji za par s dvoje djece i ukupnom bruto plaćom od 133\% AGW-a (2A-100/332C), nego za obitelj s istim dohotkom, ali bez djece (2A-100/33-NC), što je posljedica dodatnog osobnog odbitka za djecu.

\section{GRAFIKON 2.}

Dekompozicija neto prosječnog poreznog klina za osnovne hipotetske jedinice: parove (Hrvatska, 2013.), u \%

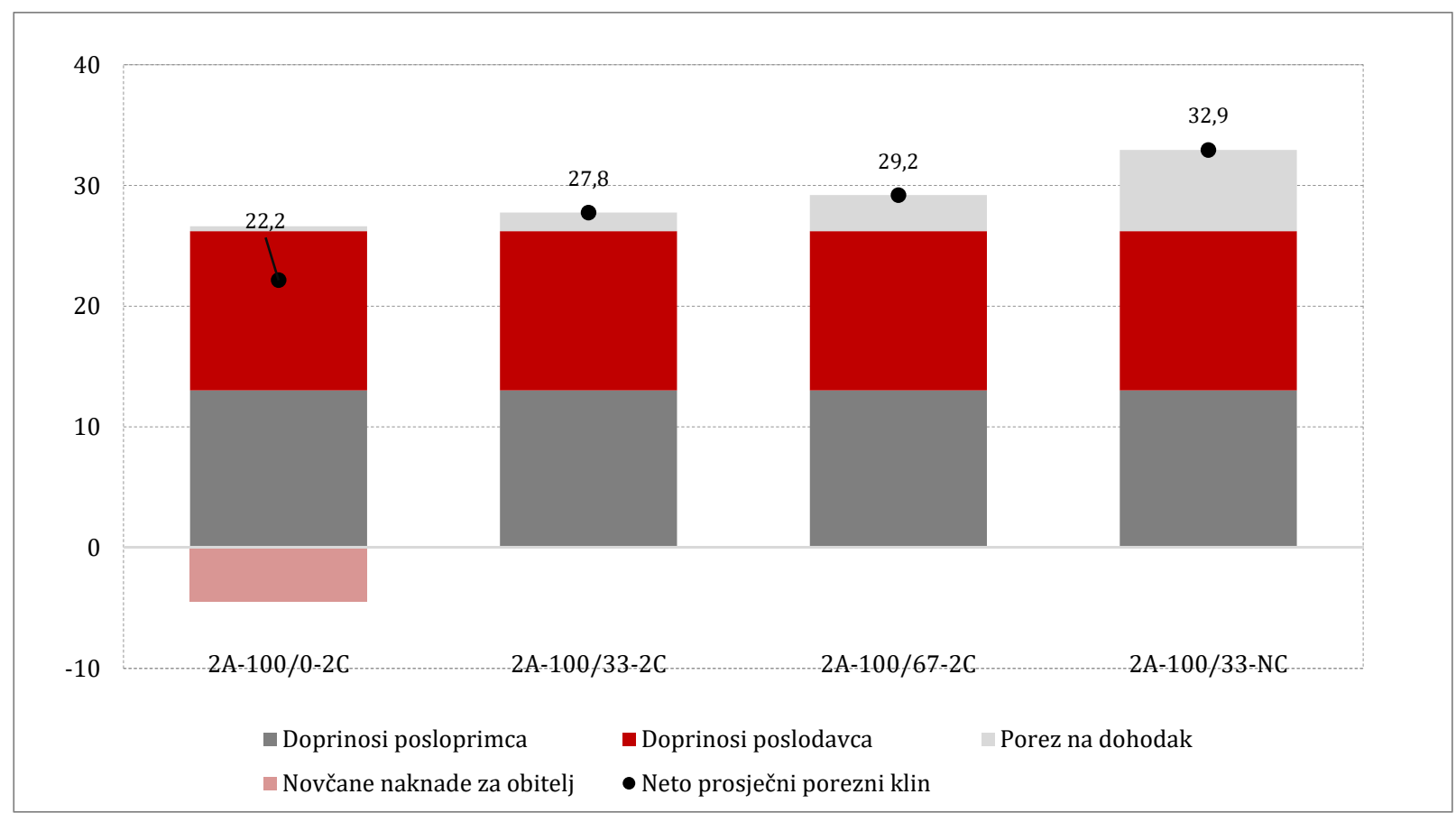

Napomena: stavka "Porez na dohodak" obuhvaća porez na dohodak i lokalni prirez. Izvor: autoričini izračuni.

Grafikon 3 prikazuje dekompoziciju neto prosječnog poreznog klina te neto prosječnu poreznu stopu za hipotetskog samca bez djece, čija se bruto plaća kreće između 50 i 250\% AGW-a. Dominantan dio poreznog klina čine doprinosi, a udio poreza na dohodak u ukupnom trošku rada raste s porastom dohotka. Progresivnost poreza na dohodak je posljedica postojanja konstantnog osobnog odbitka te progresivnog poreznog rasporeda. Neto prosječna porezna stopa se kreće od $18,1 \%$ za najniži, do $36,5 \%$ za najviši prikazani dohodak.

Grafikon 4 prikazuje dekompoziciju neto prosječnog poreznog klina te neto prosječnu poreznu stopu za hipotetski par s dvoje djece, u kojem jedan supružnik ne radi, a drugi ostvaruje bruto plaću između 50 i 250\% AGW-a. Porez na dohodak se ne plaća ako je bruto plaća manja ili jednaka $100 \%$ AGW-a. Za bruto plaću iznad 100\% AGW-a, udio poreza na dohodak postaje pozitivan i raste. Udio doprinosa u ukupnim troškovima rada je konstantan. Porezni klin umanjuju novčane naknade koje obitelj s bruto plaćom nižom od 110\% AGW-a prima u obliku doplatka za djecu. 
GRAFIKON 3.

Dekompozicija neto prosječnog poreznog klina za samca bez djece, s bruto plaćom u rasponu od 50 do 250\% AGW-a (Hrvatska, 2013.), u \%

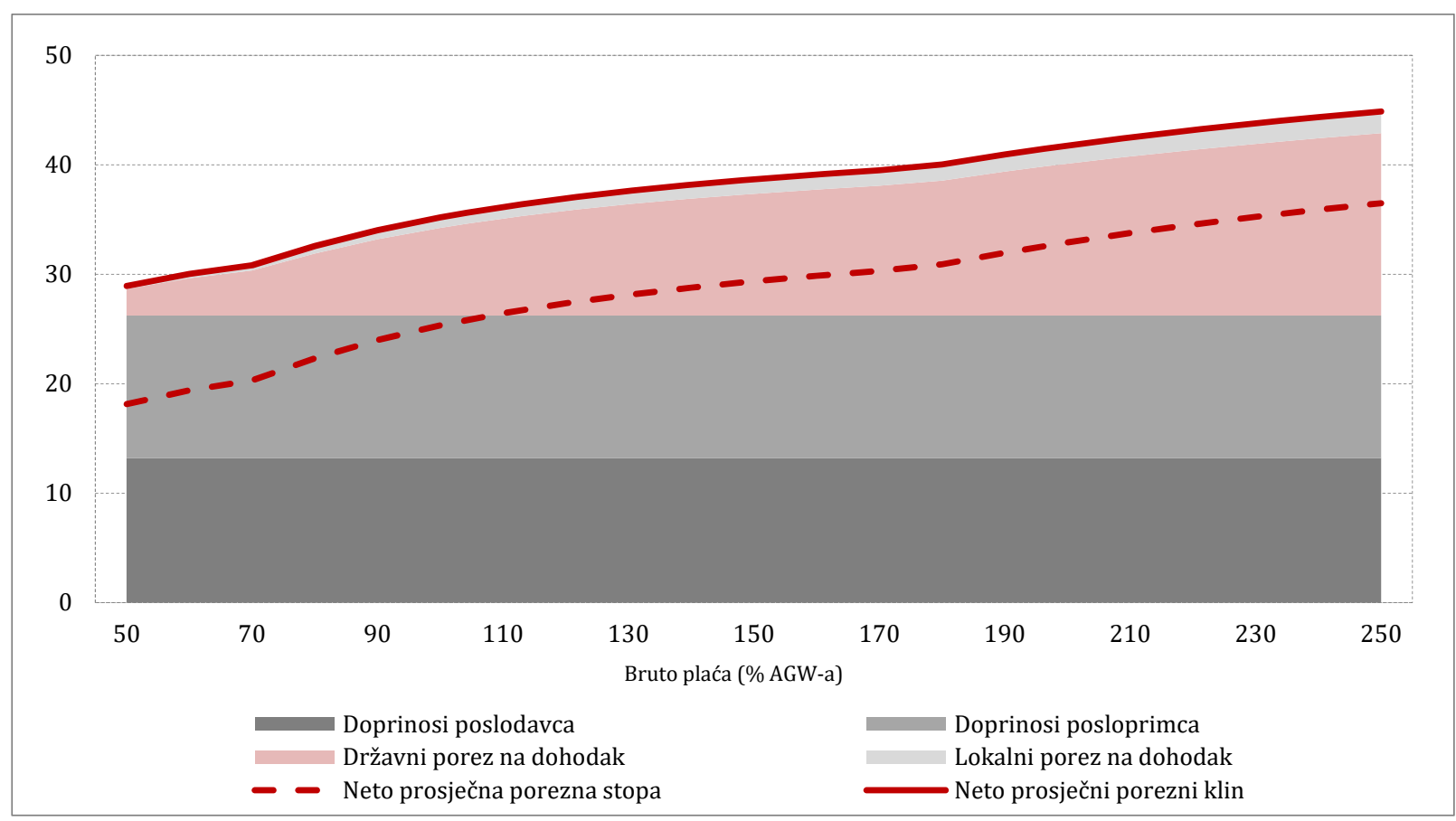

Izvor: autoričini izračuni.

\section{GRAFIKON 4.}

Dekompozicija neto prosječnog poreznog klina za par s dvoje djece, u kojem jedan supružnik ne radi, a drugi ostvaruje bruto plaću u rasponu od 50 do 250\% AGW-a (Hrvatska, 2013.), u \%

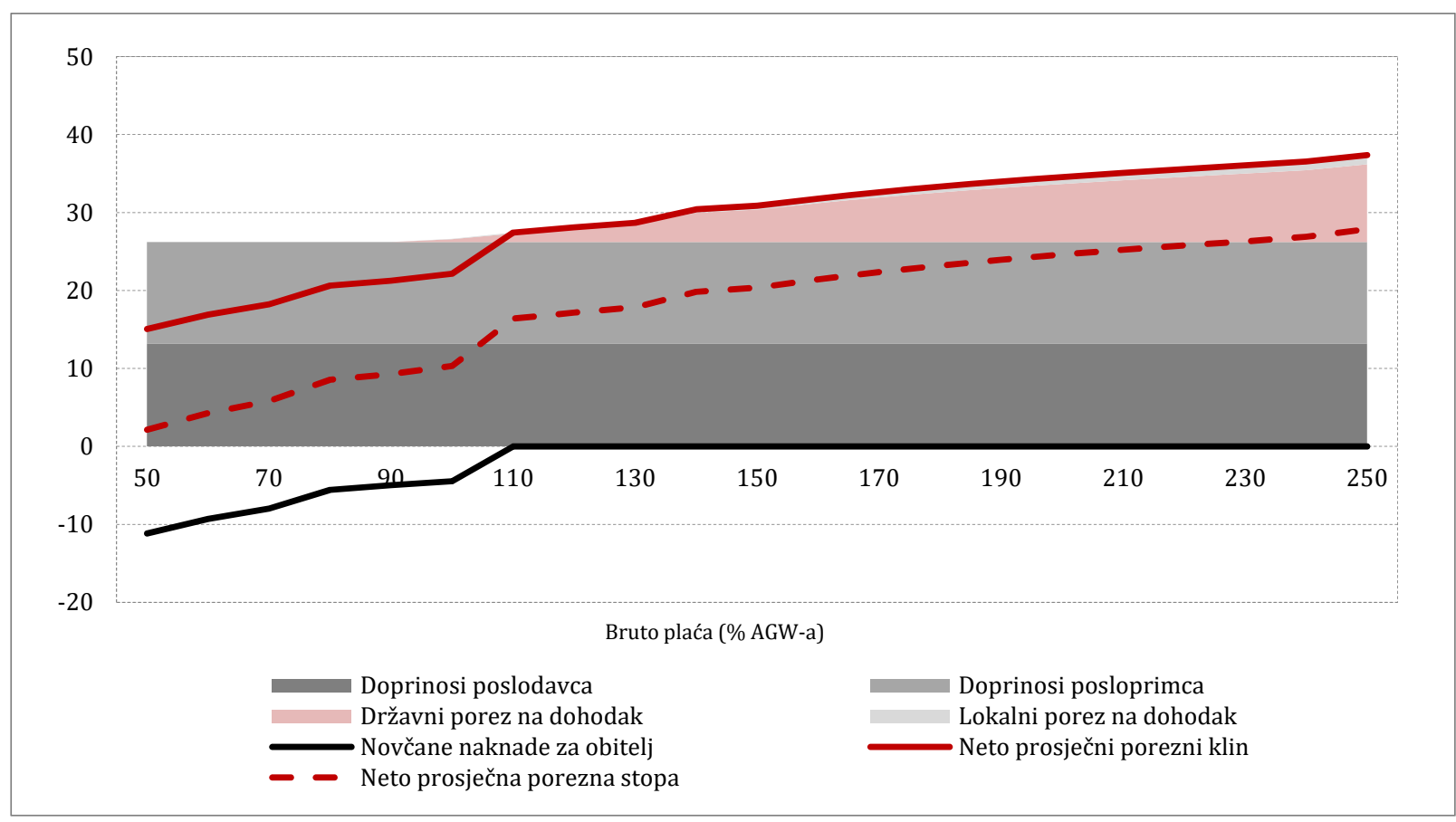

Izvor: autoričini izračuni. 


\subsection{BELGIJA}

Opis sustava oporezivanja dohotka od rada za Belgiju nalazi se u dodatku A2.

Grafikon 5 prikazuje neto prosječni porezni klin i njegovu dekompoziciju za osnovne hipotetske jedinice - samce. Porezni klin je raščlanjen na doprinose posloprimca i doprinose poslodavca, porez na dohodak te novčane naknade. Kod samaca su udjeli doprinosa u ukupnom trošku rada podjednaki za sve razine dohotka zbog jedinstvenih stopa doprinosa, a razliku u ukupnom poreznom opterećenju stvara porez na dohodak. Postoje novčane naknade za obitelji s djecom, no nisu vezane uz dohodak. Samac s dvoje djece, koji ostvaruje bruto plaću u visini 67\% AGW-a (1A67-2C), prima novčanu naknadu što mu smanjuje porezno opterećenje te neto prosječni porezni klin iznosi 36,5\%. Porezni klin na plaću samca bez djece s bruto plaćom od 167\% AGW-a (1A-167NC) iznosi 60,9\%. Može se zaključiti da je oporezivanje dohotka od rada samca bez djece progresivno zahvaljujući porezu na dohodak.

\section{GRAFIKON 5.}

Dekompozicija neto prosječnog poreznog klina za osnovne hipotetske jedinice s jednim odraslim članom (Belgija, 2013.), u \%

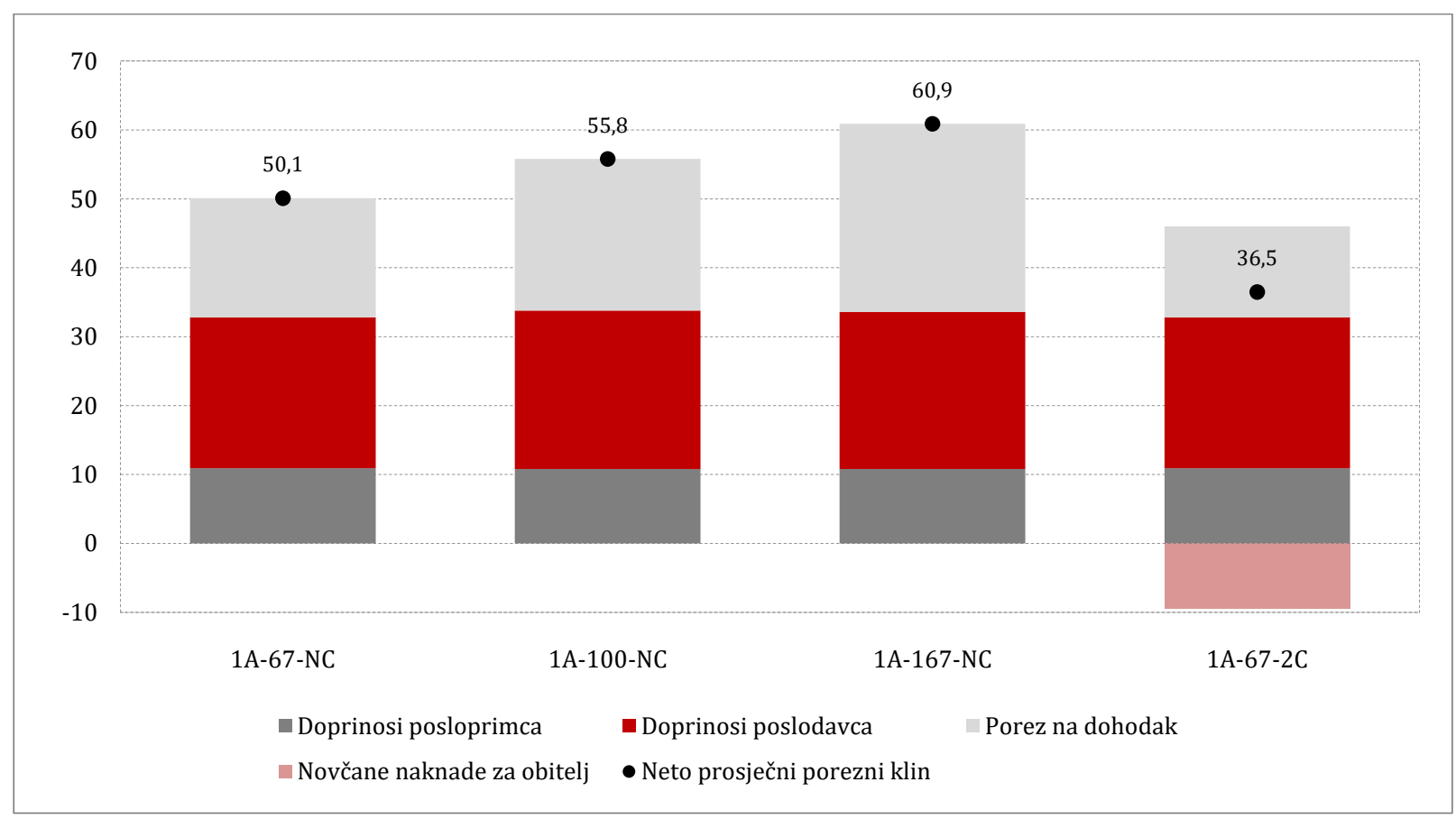

Napomena: stavka "Porez na dohodak" obuhvaća porez na dohodak i lokalni prirez. Izvor: autoričini izračuni.

Grafikon 6 prikazuje dekompoziciju neto prosječnog poreznog klina za osnovne hipotetske jedinice - parove. Razlike u poreznom klinu dijelom nastaju zbog novčanih naknada za obitelji s djecom. Za razliku od samaca, gdje su udjeli doprinosa podjednaki, ovdje postoje razlike u udjelima doprinosa, koji proizlaze iz prava na umanjenje doprinosa u slučaju niskog dohotka, a koje ostvaruje supružnik s bruto plaćom od 33\% AGW-a. 
GRAFIKON 6.

Dekompozicija neto prosječnog poreznog klina za osnovne hipotetske jedinice: parove (Belgija, 2013.), u \%

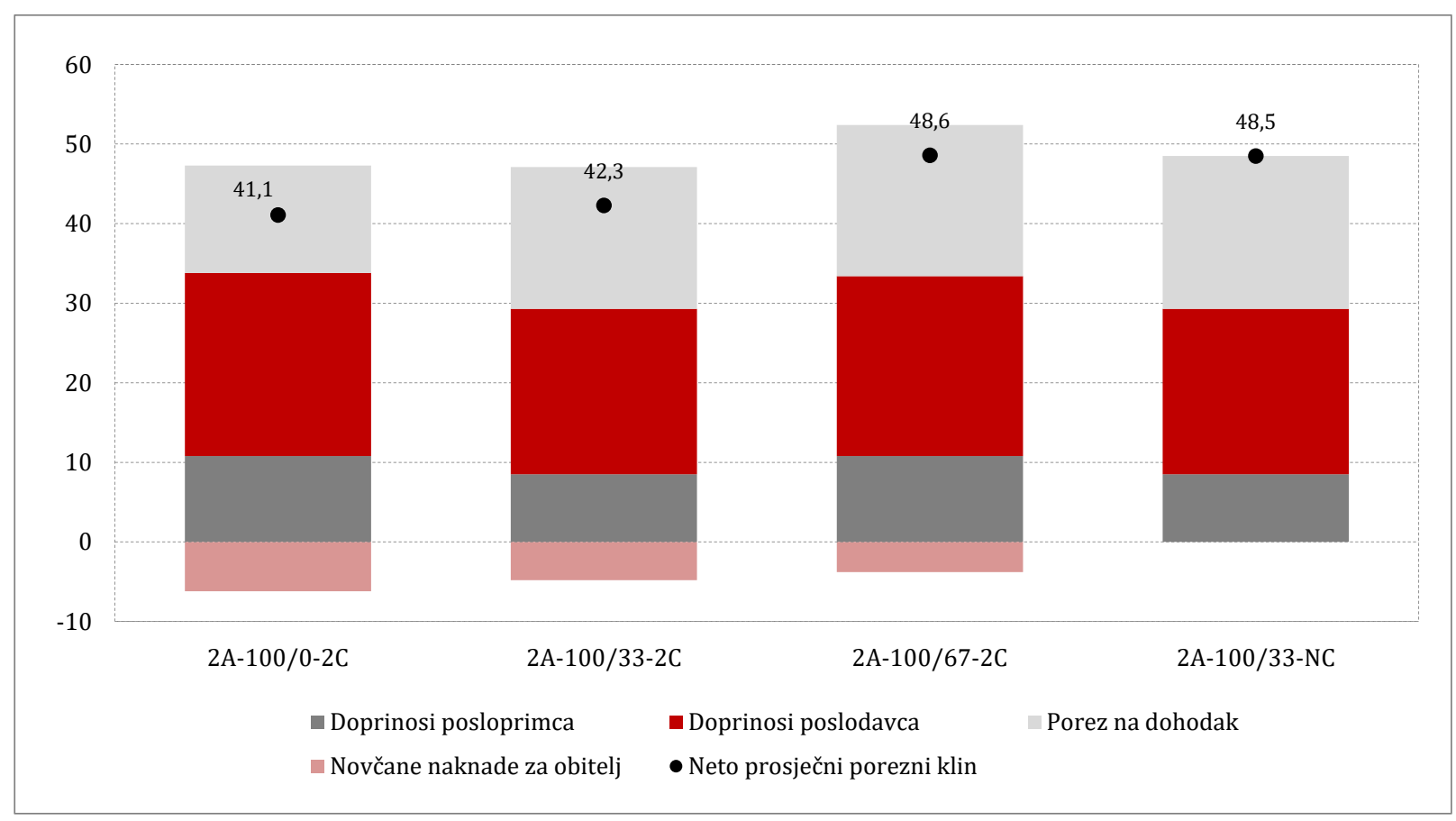

Napomena: stavka "Porez na dohodak" obuhvaća porez na dohodak i lokalni prirez. Izvor: autoričini izračuni.

\section{GRAFIKON 7.}

Dekompozicija neto prosječnog poreznog klina za samca bez djece, s bruto plaćom u rasponu od 50 do 250\% AGW-a (Belgija, 2013.), u \%

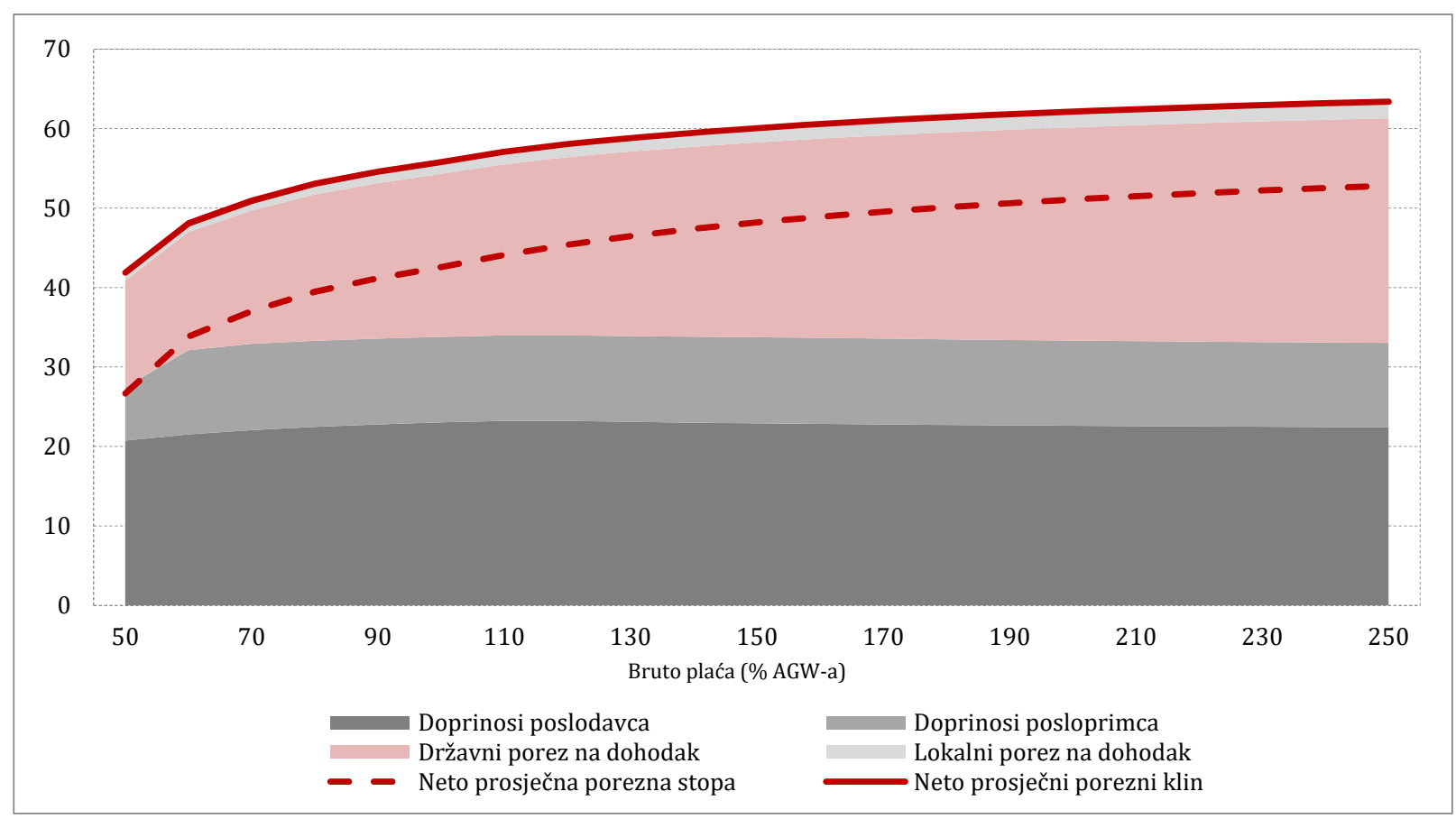

Izvor: autoričini izračuni. 
Grafikon 7 prikazuje dekompoziciju neto prosječnog poreznog klina te neto prosječnu poreznu stopu za hipotetskog samca bez djece, čija se bruto plaća kreće između 50 i 250\% AGW-a. Porezni klin za promatrani raspon bruto plaće kreće se između 41,8 i 63,4\%. Glavni dio opterećenja čine poslodavčevi doprinosi s oko $20 \%$ te doprinosi posloprimca. Kod doprinosa posloprimca primjećuje se niži udio za bruto plaće koje iznose 50 i $60 \%$ AGW-a. To je posljedica prava na umanjenje obaveze za doprinose posloprimca s niskim dohotkom. Porez na dohodak predstavlja 13,4\% ukupnog troška rada za bruto plaću od 50\% AGW-a, a 28\% za bruto plaću od 250\% AGW-a, što znači da je porez na dohodak zaslužan za progresivnost u slučaju samca.

Grafikon 8 prikazuje dekompoziciju neto prosječnog poreznog klina te neto prosječnu poreznu stopu za hipotetski par s dvoje djece, u kojem jedan supružnik ne radi, a drugi ostvaruje bruto plaću između 50 i 250\% AGW-a. Novčane naknade smanjuju ukupni porezni klin te se on kreće od 15,7\%, za razinu bruto plaće od 50\% AGW-a, do 57,1\% za bruto plaću od $250 \%$ AGW-a. Novčane naknade povećavaju progresivnost oporezivanja. Ponovno se uočava "anomalija" kod doprinosa, a koja je posljedica umanjenja doprinosa za niske bruto plaće. Porez na dohodak je progresivan. Za najnižu promatranu razinu dohotka njegov udio u ukupnom trošku rada je 1,0\%, a za najveću $24,7 \%$. Neto prosječna porezna stopa se kreće od $-6 \%$ za najnižu, do $44 \%$ za najvišu razinu dohotka.

\section{GRAFIKON 8.}

Dekompozicija neto prosječnog poreznog klina za par s dvoje djece, u kojem jedan supružnik ne radi, a drugi ostvaruje bruto plaću u rasponu od 50 do 250\% AGW-a (Belgija, 2013.), u \%

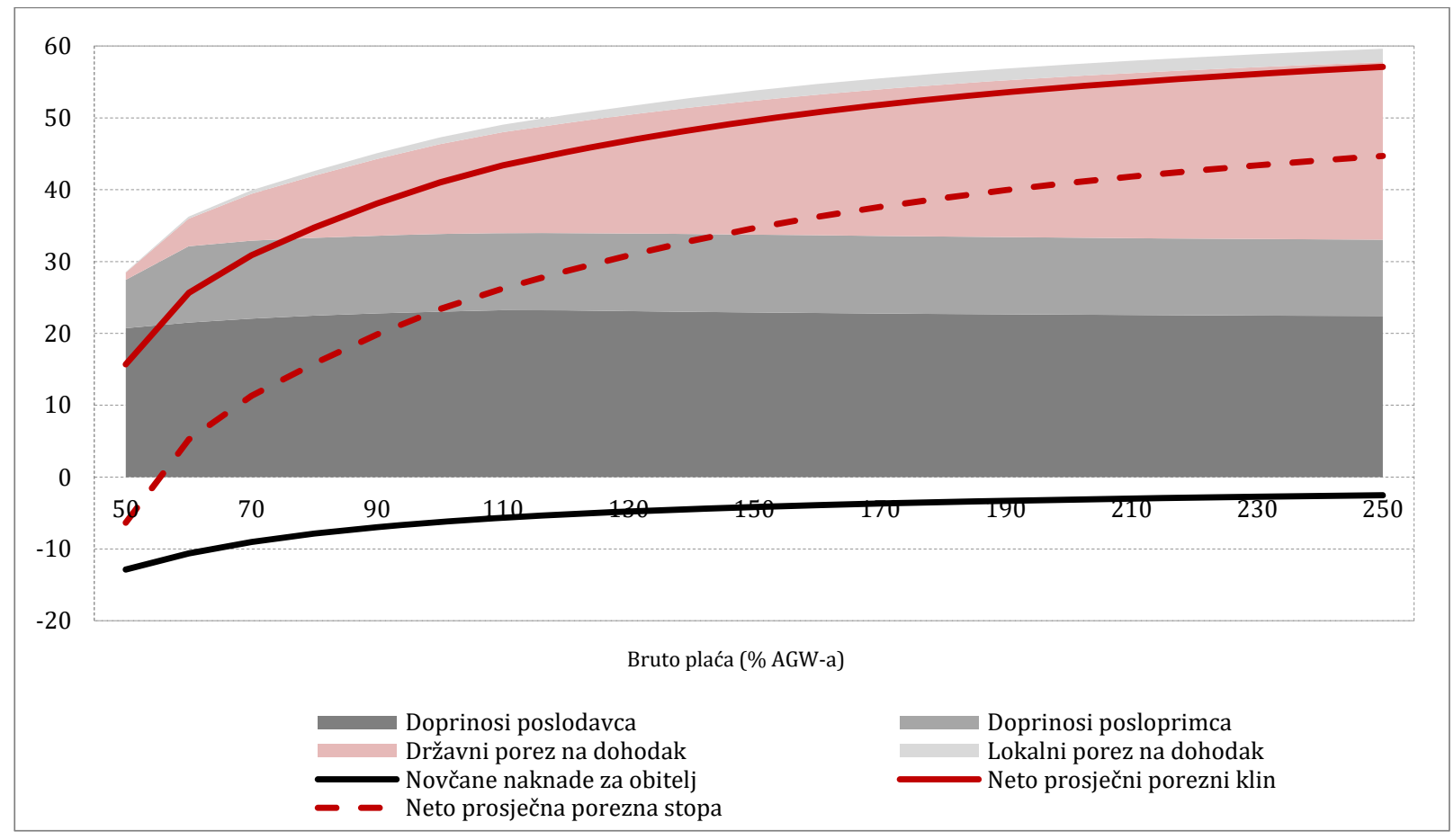

Izvor: autoričini izračuni. 


\subsection{ESTONIJA}

Opis sustava oporezivanja dohotka od rada za Estoniju nalazi se u dodatku A3.

Grafikon 9 prikazuje neto prosječni porezni klin i njegovu dekompoziciju za osnovne hipotetske jedinice - samce. Udio doprinosa je konstantan u ukupnim troškovima rada. Udio poreza u ukupnim troškovima rada je manji za obitelj koja ima dvoje djece što je posljedica prava na veću poreznu olakšicu. Uzrok razlika u udjelima poreza na dohodak u ukupnim troškovima rada su konstantne olakšice, čija relativna značajnost opada s porastom dohotka pa pojedinac s većim dohotkom ima relativno veću poreznu obavezu. Novčane naknade za djecu umanjuju porezni klin hipotetske jedinice 1A-67-2C u odnosu na samce bez djece.

\section{GRAFIKON 9.}

Dekompozicija neto prosječnog poreznog klina za osnovne hipotetske jedinice: samce (Estonija, 2013.), u \%

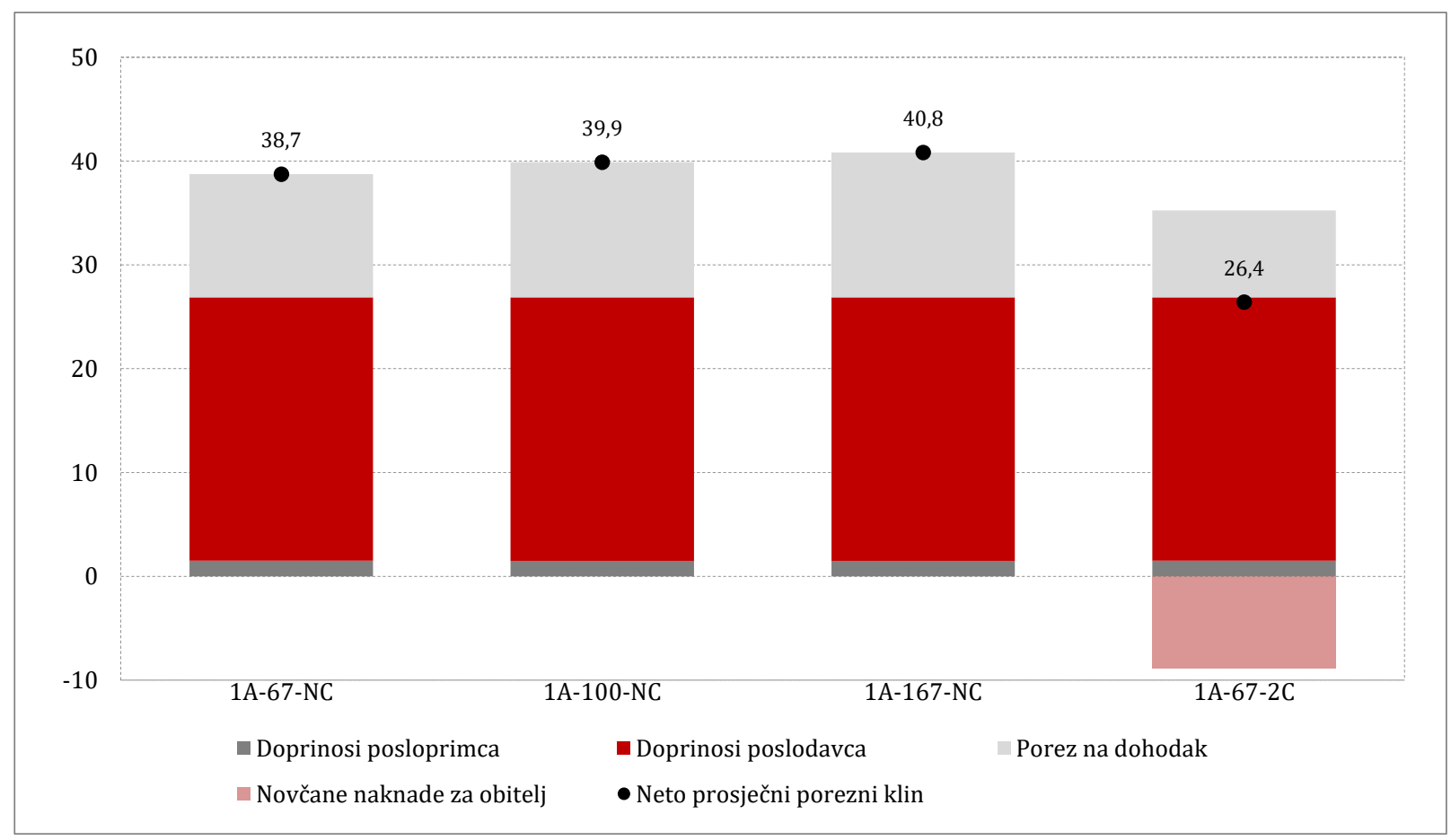

Izvor: autoričini izračuni.

Grafikon 10 prikazuje dekompoziciju neto prosječnog poreznog klina za osnovne hipotetske jedinice - parove. Udio doprinosa je konstantan. Razlike u udjelima poreza na dohodak u ukupnim troškovima rada proizlaze iz razlike u broju djece i razlike u dohotku. Obitelji koje imaju djecu imaju pravo na veće porezne olakšice čime se umanjuje njihova porezna osnovica. Porezne olakšice su konstantne, što je relativno povoljnije za obitelji s nižim dohotkom. Budući da Estonija ima jedinstvenu stopu poreza na dohodak, blaga progresivnost tog poreza proizlazi iz poreznih olakšica. Progresivnosti ukupnog sustava u određenoj mjeri pridonose i novčane naknade za djecu. 
GRAFIKON 10.

Dekompozicija neto prosječnog poreznog klina za osnovne hipotetske jedinice: parove (Estonija, 2013.), u \%

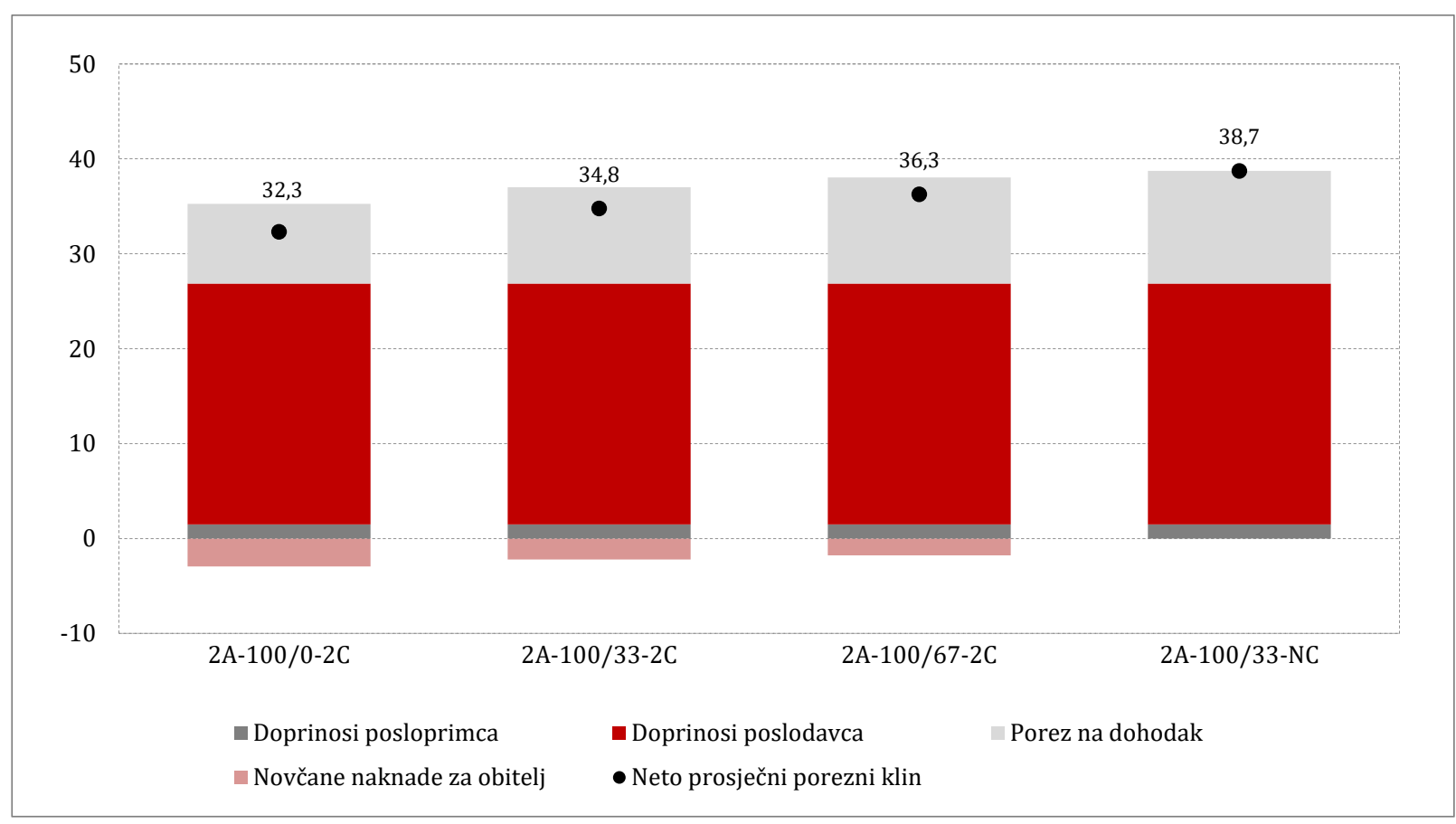

Izvor: autoričini izračuni.

\section{GRAFIKON 11.}

Dekompozicija neto prosječnog poreznog klina za samca bez djece, s bruto plaćom u rasponu od 50 do 250\% AGW-a (Estonija, 2013.), u \%

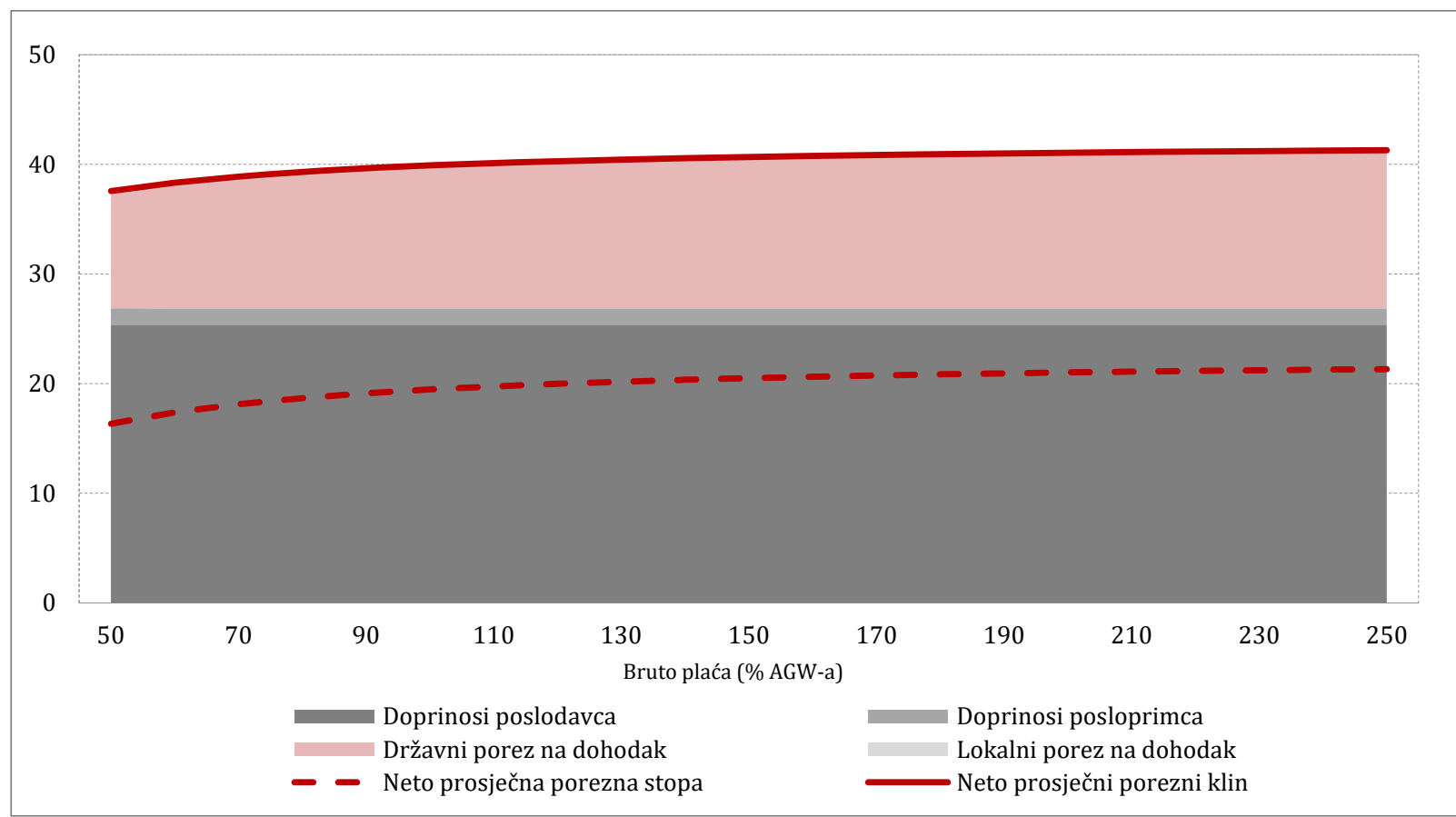

Izvor: autoričini izračuni.

Grafikon 11 prikazuje dekompoziciju neto prosječnog poreznog klina te neto prosječnu poreznu stopu za hipotetskog samca bez djece, čija se bruto plaća kreće između 50 i 250\% AGW-a. Za razinu 
bruto plaće od 50\% AGW-a porezni klin iznosi 37,6\%, a za najveću promatranu razinu bruto plaće, od 250\% AGW-a, iznosi 41,3\%. Najveći dio poreznog klina, 25,4\% ukupnog troška rada, odnosi se na doprinose poslodavca. Doprinosi posloprimca čine oko 1,5\% ukupnog troška rada, a udio poreza na dohodak kreće se između 10,7 i 14,4\% ukupnog troška rada. Uočava se vrlo blaga progresivnost sustava, a rezultat su osnovnog osobnog odbitka koji je jednakog iznosa za sve obveznike. Neto prosječna porezna stopa se kreće između 16,4 i 21,3\%.

Grafikon 12 prikazuje dekompoziciju neto prosječnog poreznog klina te neto prosječnu poreznu stopu za hipotetski par s dvoje djece, u kojem jedan supružnik ne radi, a drugi ostvaruje bruto plaću između 50 i 250\% AGW-a. Kao i kod samca, udio doprinosa je konstantan zahvaljujući proporcionalnim stopama doprinosa i nepostojanju najviše osnovice. Udio poreza na dohodak raste s povećanjem bruto plaće što je posljedica konstantnih poreznih olakšica. Porezni klin se kreće od 22,4 do 38,2\%. Novčane naknade za djecu su konstantne pa čine sustav progresivnijim, jer se više odražavaju u ukupnim troškovima rada za obitelji s nižim razinama dohotka. Neto prosječna porezna stopa kreće se od $-4 \%$ za najniže dohotke do $17,3 \%$ za najvišu razinu dohotka. Dakle, progresivnost je ovdje veća nego u slučaju samca, zahvaljujući relativno visokim poreznim odbicima i novčanoj naknadi za djecu.

\section{GRAFIKON 12.}

Dekompozicija neto prosječnog poreznog klina za par s dvoje djece, u kojem jedan supružnik ne radi, a drugi ostvaruje bruto plaću u rasponu od 50 do 250\% AGW-a (Estonija, 2013.), u \%

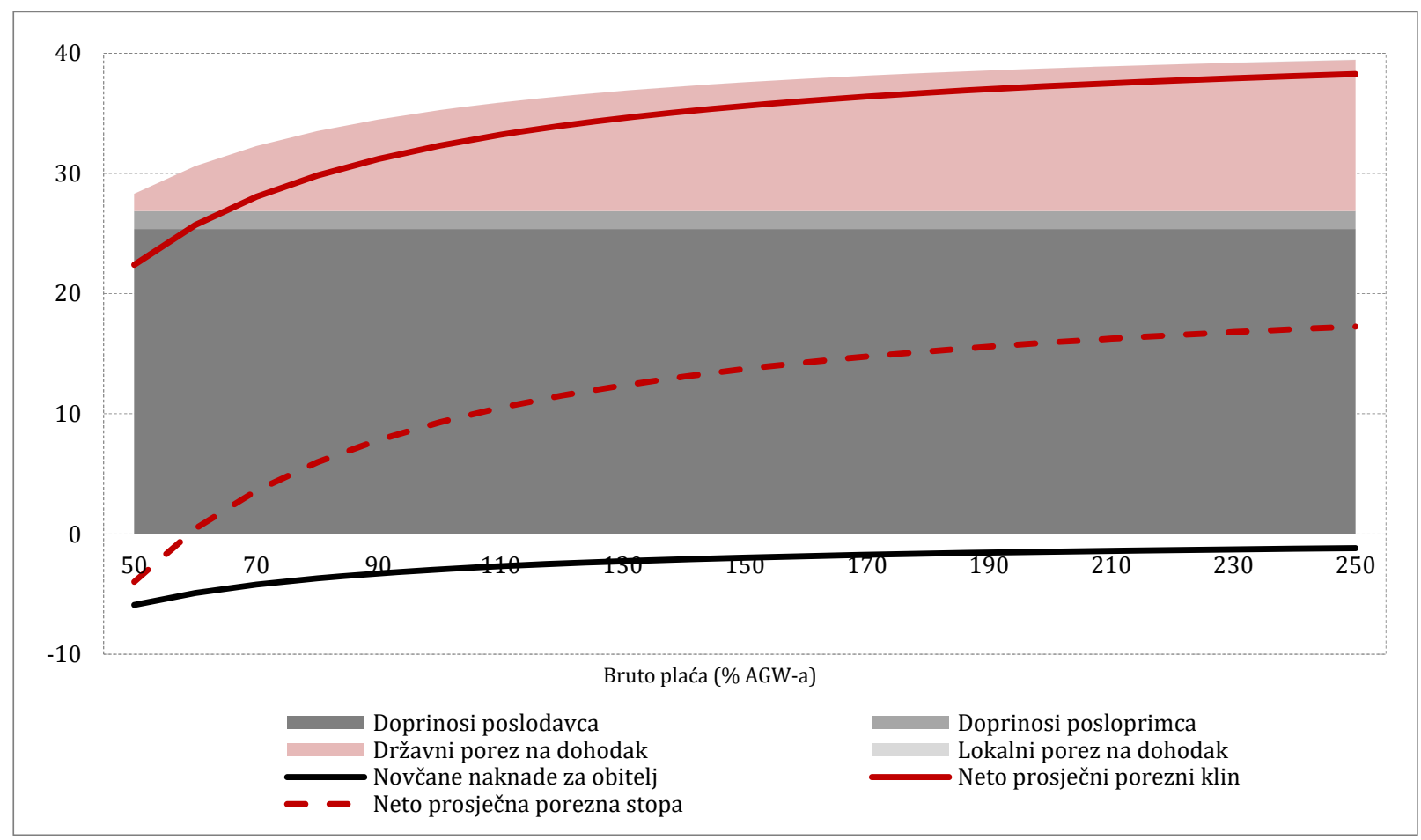

Izvor: autoričini izračuni. 


\subsection{NJEMAČKA}

Opis sustava oporezivanja dohotka od rada za Njemačku nalazi se u dodatku A4.

Grafikon 13 prikazuje neto prosječni porezni klin i njegovu dekompoziciju za osnovne hipotetske jedinice - samce. Specifičnost njemačkog sustava je relativno niska najviša osnovica za obračun doprinosa. Zbog toga hipotetska jedinica 1A-167-NC ima niži udio doprinosa u poreznom klinu nego jedinice s nižom bruto plaćom, 1A-67-NC i 1A-100-NC. Međutim, progresivni porez na dohodak služi kao "kompenzator" pa je sustav u cijelosti progresivan. Zahvaljujući umanjenju poreza za djecu učinak poreza na dohodak na porezni klin je negativan za samca s dvoje djece i bruto plaćom od 67\% AGW-a (1A-67-2C).

\section{GRAFIKON 13.}

Dekompozicija neto prosječnog poreznog klina za osnovne hipotetske jedinice: samce (Njemačka, 2013.), u \%

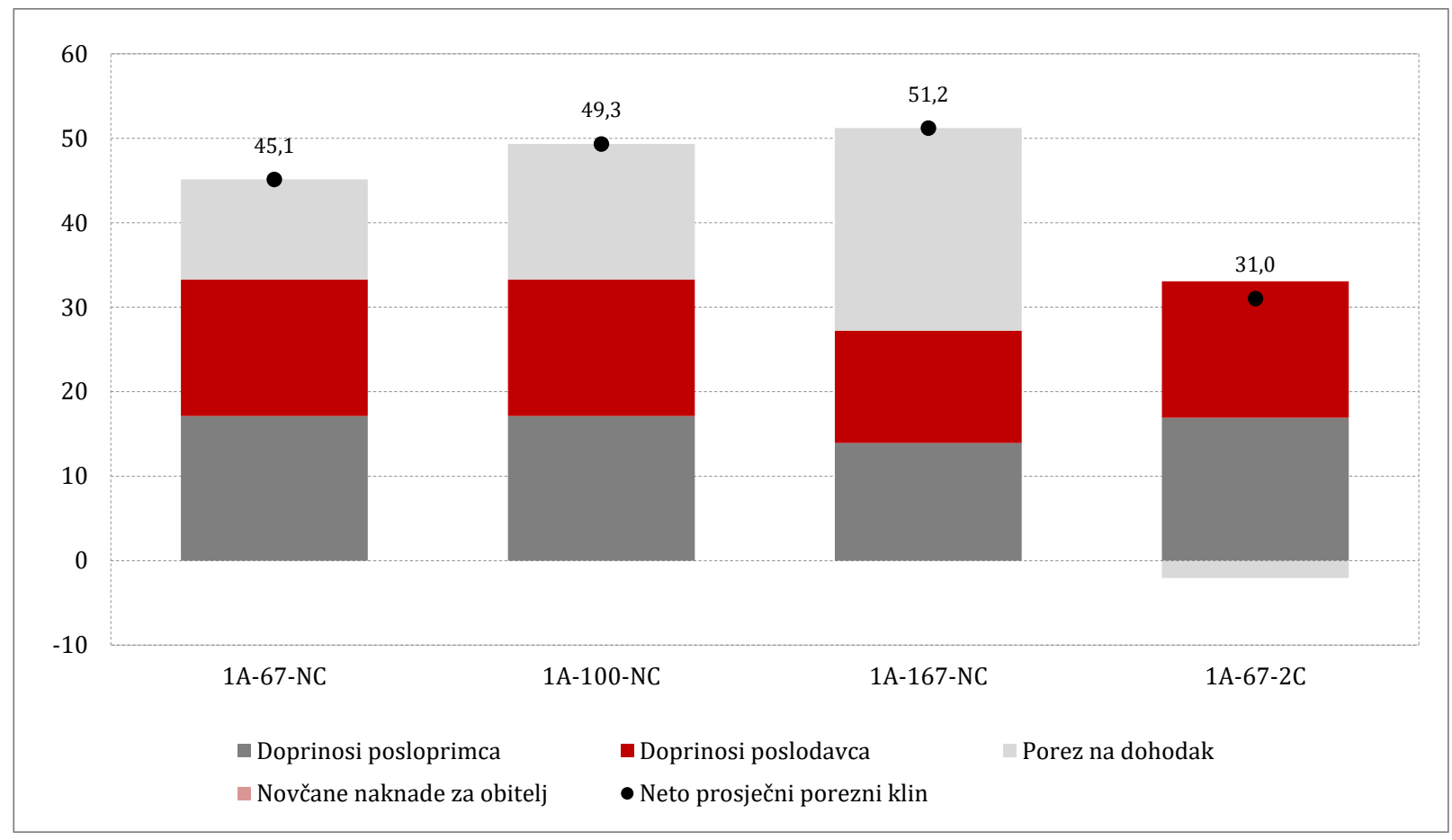

Izvor: autoričini izračuni.

Grafikon 14 prikazuje dekompoziciju neto prosječnog poreznog klina za osnovne hipotetske jedinice - parove. Udjeli doprinosa u ukupnom trošku rada za promatrane parove su podjednaki zbog pravila da se dohodak prilikom oporezivanja supružnika dijeli na dva jednaka dijela, pa svaki od tih dijelova ne prelazi granicu iznad koje bi doprinosi postali konstantni (150\% prosječnog bruto dohotka). Udio poreza na dohodak u ukupnom trošku rada najmanji je za par 2A-100/0-2C (33,8\%), čija je ukupna bruto plaća manja od parova 2A-100/33-2C i 2A-100/67-2C. Par 2A100/33-NC ima najveći porezni klin $(45,1 \%)$, koji je za 6,5 postotnih bodova veći od poreznog klina para s jednakom ukupnom bruto plaćom i dvoje djece (2A-100/33-2C), a razlika proizlazi iz poreznih olakšica za djecu. 
GRAFIKON 14.

Dekompozicija neto prosječnog poreznog klina za osnovne hipotetske jedinice: parove (Njemačka, 2013.), u \%

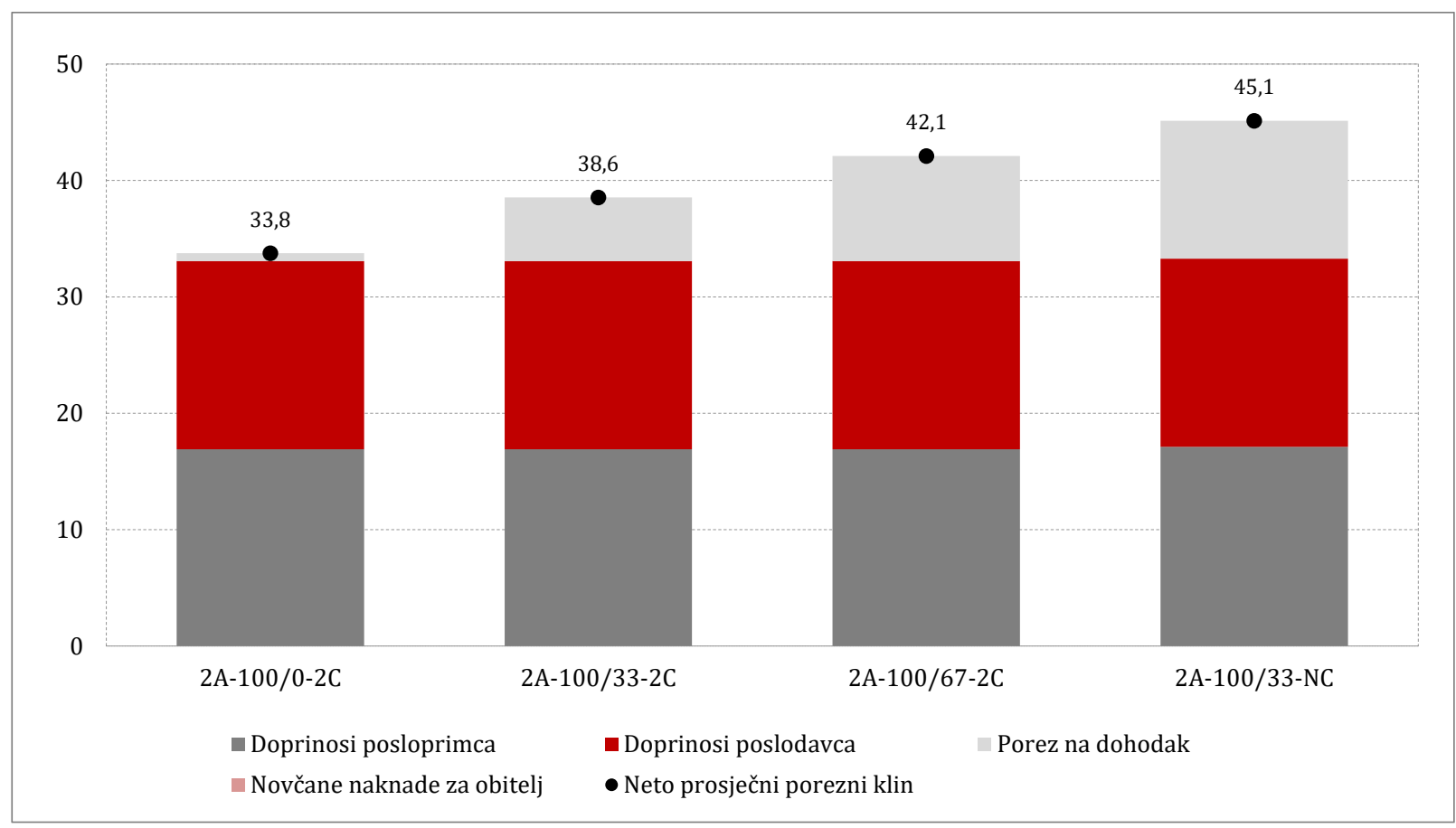

Izvor: autoričini izračuni.

\section{GRAFIKON 15.}

Dekompozicija neto prosječnog poreznog klina za samca bez djece, s bruto plaćom u rasponu od 50 do 250\% AGW-a (Njemačka, 2013.), u \%



Izvor: autoričini izračuni. 
Grafikon 15 prikazuje dekompoziciju neto prosječnog poreznog klina te neto prosječnu poreznu stopu za hipotetskog samca bez djece, čija se bruto plaća kreće između 50 i 250\% AGW-a. Kod nižih razina bruto plaće dominantan dio poreznog klina čine doprinosi. Kod većih razina dohotka udio doprinosa počinje opadati zbog najviše osnovice za doprinose, a dominantnu ulogu u poreznom klinu preuzima porez na dohodak. Za najveću promatranu razinu bruto plaće udio poreza na dohodak u ukupnom trošku rada iznosi $30 \%$. Za razliku od ostalih promatranih zemalja, porezni klin u Njemačkoj nije "monotono rastući". Kod bruto plaće jednake 150\% AGW-a, porezni klin doseže svoj maksimum i zatim lagano pada. To je posljedica najviše osnovice za doprinose, koji stoga imaju regresivan učinak na sustav oporezivanja dohotka. Porez na dohodak nakon spomenute granice od $150 \%$ AGW-a ipak ne može kompenzirati regresivnost doprinosa. Neto prosječna porezna stopa se kreće od 30,9 do $43,9 \%$.

Grafikon 16 prikazuje dekompoziciju neto prosječnog poreznog klina te neto prosječnu poreznu stopu za hipotetski par s dvoje djece, u kojem jedan supružnik ne radi, a drugi ostvaruje bruto plaću između 50 i 250\% AGW-a. Neto prosječna porezna stopa se kreće od 1,7 do 29,2\%. Opet se primjećuje opadajući udio doprinosa u ukupnom trošku rada, što čini oporezivanje regresivnim. Porez na dohodak je progresivan, tj. njegov udio u troškovima rada raste kako se dohodak povećava. Za niske razine dohotka on je negativan jer osnovice za umanjenje poreza dobivene za djecu premašuju iznos početnog iznosa poreza.

\section{GRAFIKON 16.}

Dekompozicija neto prosječnog poreznog klina za par s dvoje djece, u kojem jedan supružnik ne radi, a drugi ostvaruje bruto plaću u rasponu od 50 do 250\% AGW-a (Njemačka, 2013.), u \%

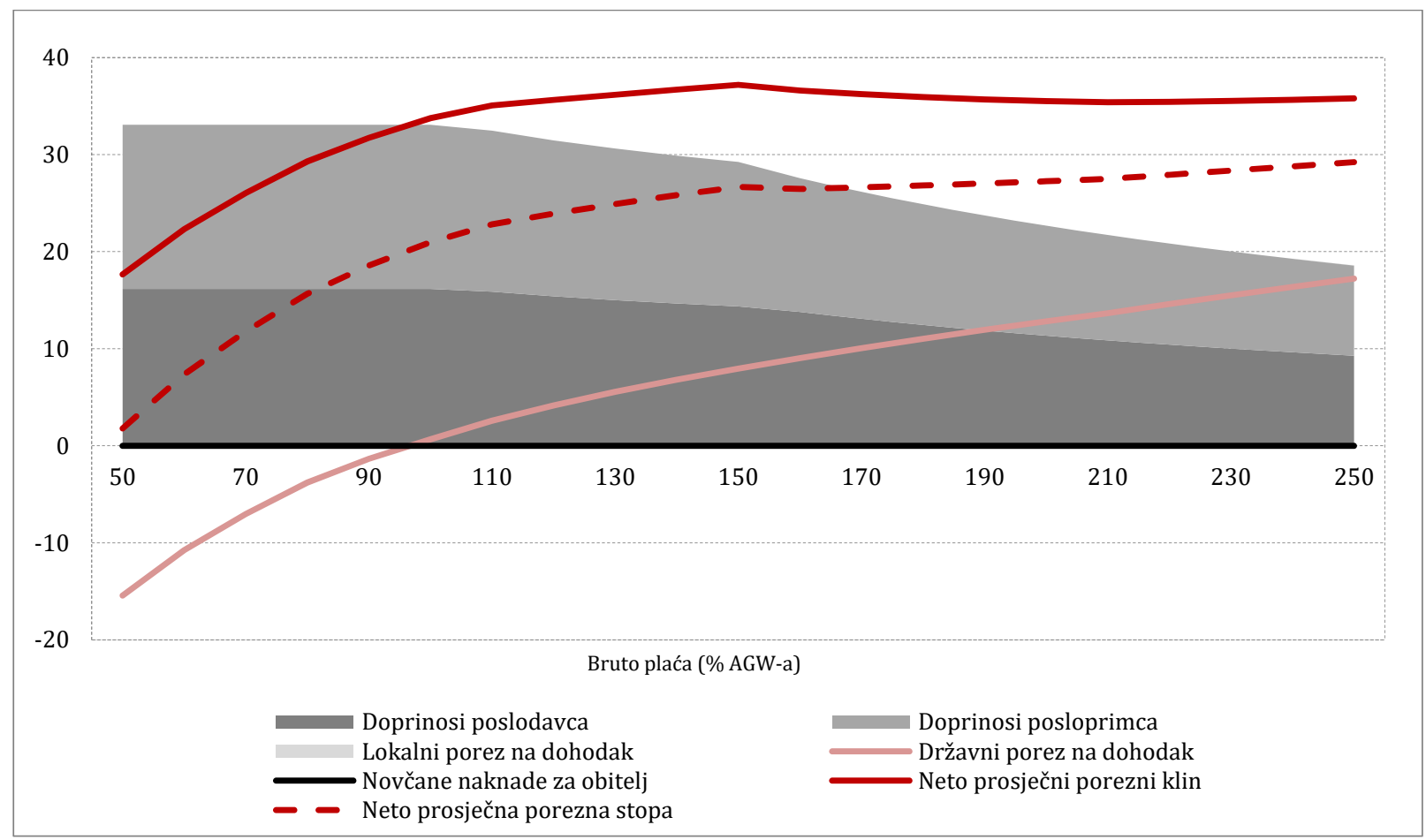

Izvor: autoričini izračuni. 


\subsection{SLOVAČKA}

Opis sustava oporezivanja dohotka od rada za Slovačku nalazi se u dodatku A5.

Grafikon 17 prikazuje neto prosječni porezni klin i njegovu dekompoziciju za osnovne hipotetske jedinice - samce. Udio doprinosa u ukupnim troškovima rada je konstantan jer ne postoje najviše osnovice za doprinose pa oni rastu proporcionalno s troškom rada. Negativan porez se javlja kod samca s dvoje djece (1A-67-2C) zahvaljujući umanjenju poreza za djecu. Porez na dohodak sam po sebi nije progresivan, jer je granica za drugi porezni razred značajno iznad iznosa dohodaka koji se ovdje razmatraju, ali ga progresivnim čine osobni odbici čiji su iznosi konstantni u odnosu na dohodak.

\section{GRAFIKON 17.}

Dekompozicija neto prosječnog poreznog klina za osnovne hipotetske jedinice: samce (Slovačka, 2013.), u \%

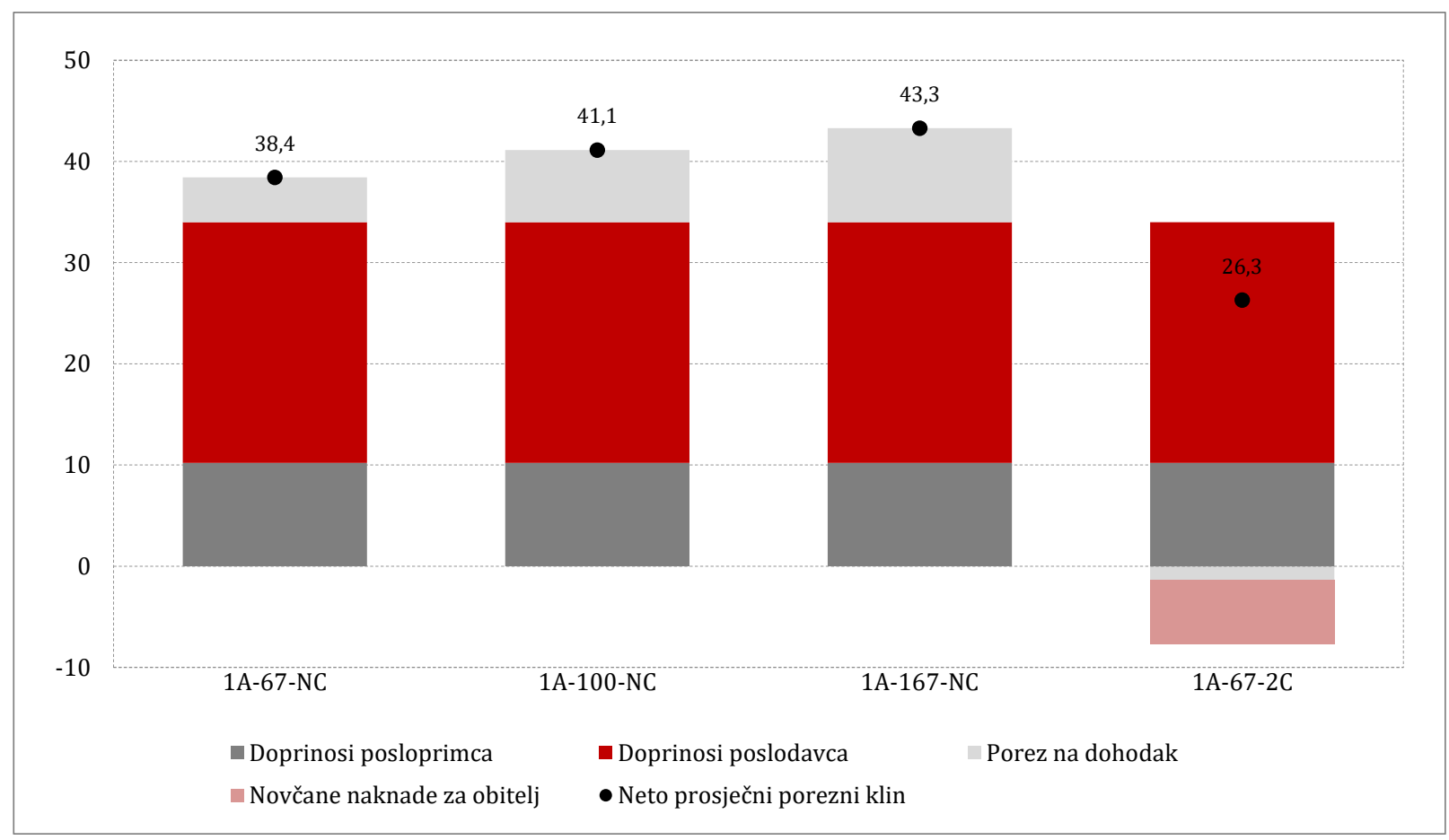

Izvor: autoričini izračuni.

Grafikon 18 prikazuje dekompoziciju neto prosječnog poreznog klina za osnovne hipotetske jedinice - parove. Udio doprinosa u ukupnim troškovima rada je konstantan. Udio poreza na dohodak je negativan kod jedinice 2A-100/0-2C, zahvaljujući umanjenju poreza za djecu. Novčane naknade za djecu dodatno umanjuju porezni klin.

Grafikon 19 prikazuje dekompoziciju neto prosječnog poreznog klina te neto prosječnu poreznu stopu za hipotetskog samca bez djece, čija se bruto plaća kreće između 50 i 250\% AGW-a. Sustav oporezivanja dohotka od rada je progresivan. Udio doprinosa je konstantan. Oporezivi dohodak ne prelazi granicu za ulazak u drugi razred, koji se oporezuje stopom od $25 \%$, što znači da se cjelokupna osnovica oporezuje po stopi od 19\%. Ipak, porez na dohodak je progresivan zahvaljujući umanjenju poreza. Naime, osnovno umanjenje poreza je jednakog apsolutnog iznosa, a nakon što dohodak prijeđe određenu razinu, počinje se smanjivati, što dodatno pojačava progresivnost. Neto prosječna porezna stopa se kreće od 15,7 do $27,4 \%$. 
GRAFIKON 18.

Dekompozicija neto prosječnog poreznog klina za osnovne hipotetske jedinice: parove (Slovačka, 2013.), u \%

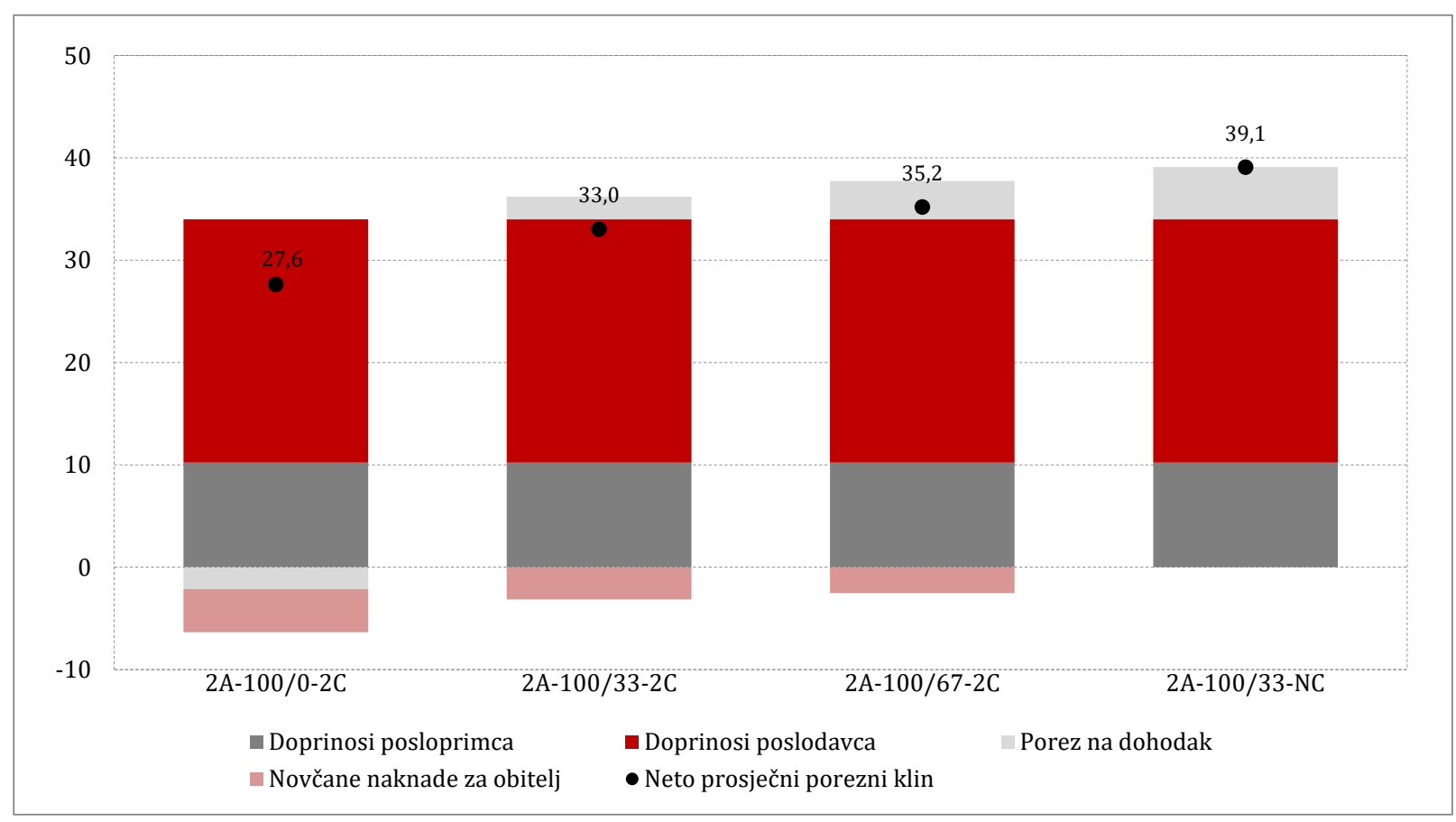

Izvor: autoričini izračuni.

\section{GRAFIKON 19.}

Dekompozicija neto prosječnog poreznog klina za samca bez djece, s bruto plaćom u rasponu od 50 do 250\% AGW-a (Slovačka, 2013.), u \%

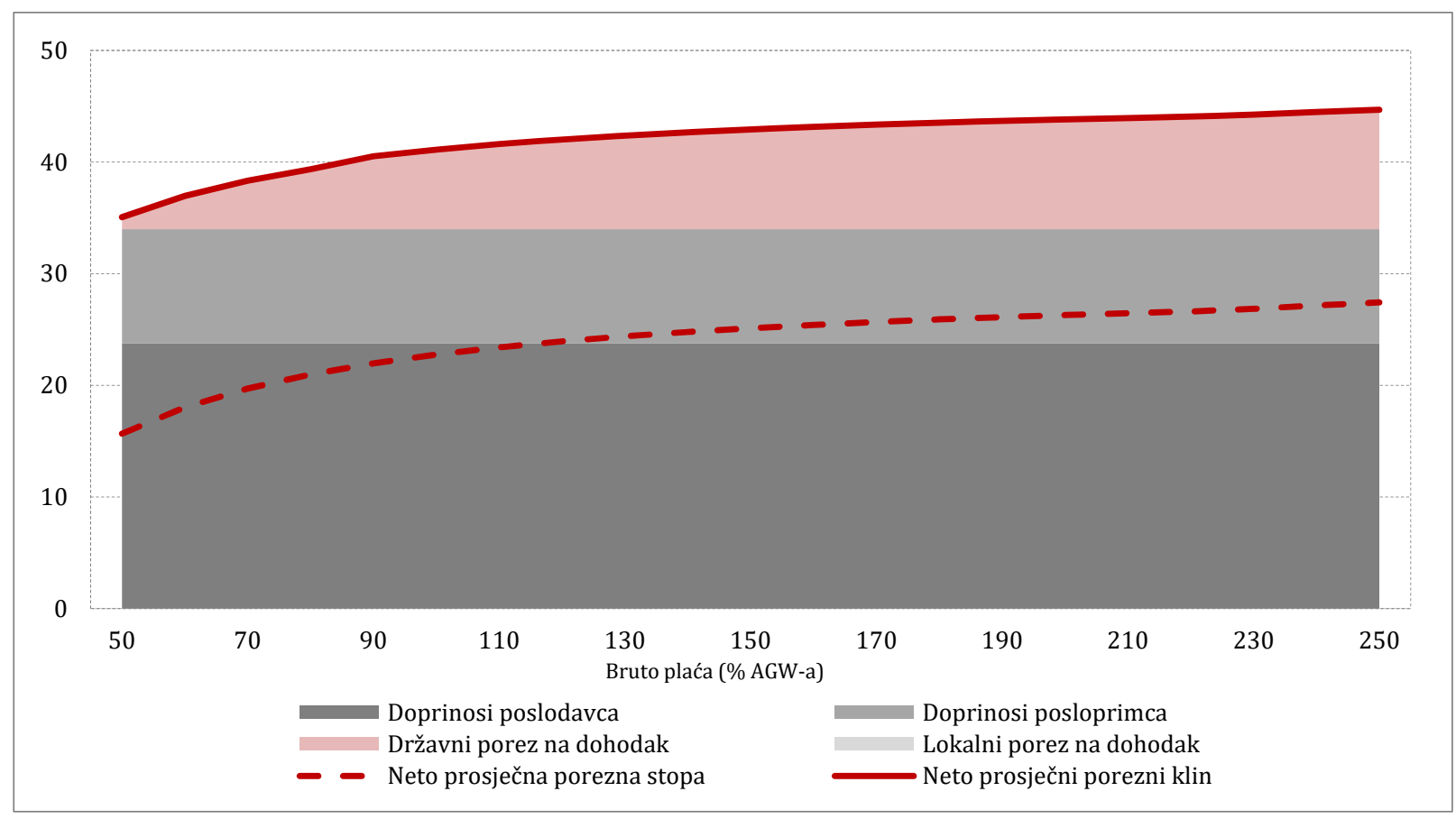

Izvor: autoričini izračuni.

Grafikon 20 prikazuje dekompoziciju neto prosječnog poreznog klina te neto prosječnu poreznu stopu za hipotetski par s dvoje djece, u kojem jedan supružnik ne radi, a drugi ostvaruje bruto plaću 
između 50 i 250\% AGW-a. Doprinosi čine konstantan dio troškova rada. Promotrimo li liniju koja predočava porezni klin, možemo zaključiti da je sustav progresivan. Razlog tome su konstantne olakšice, ali i novčane naknade za djecu.

\section{GRAFIKON 20.}

Dekompozicija neto prosječnog poreznog klina za par s dvoje djece, u kojem jedan supružnik ne radi, a drugi ostvaruje bruto plaću u rasponu od 50 do 250\% AGW-a (Slovačka, 2013.), u \%

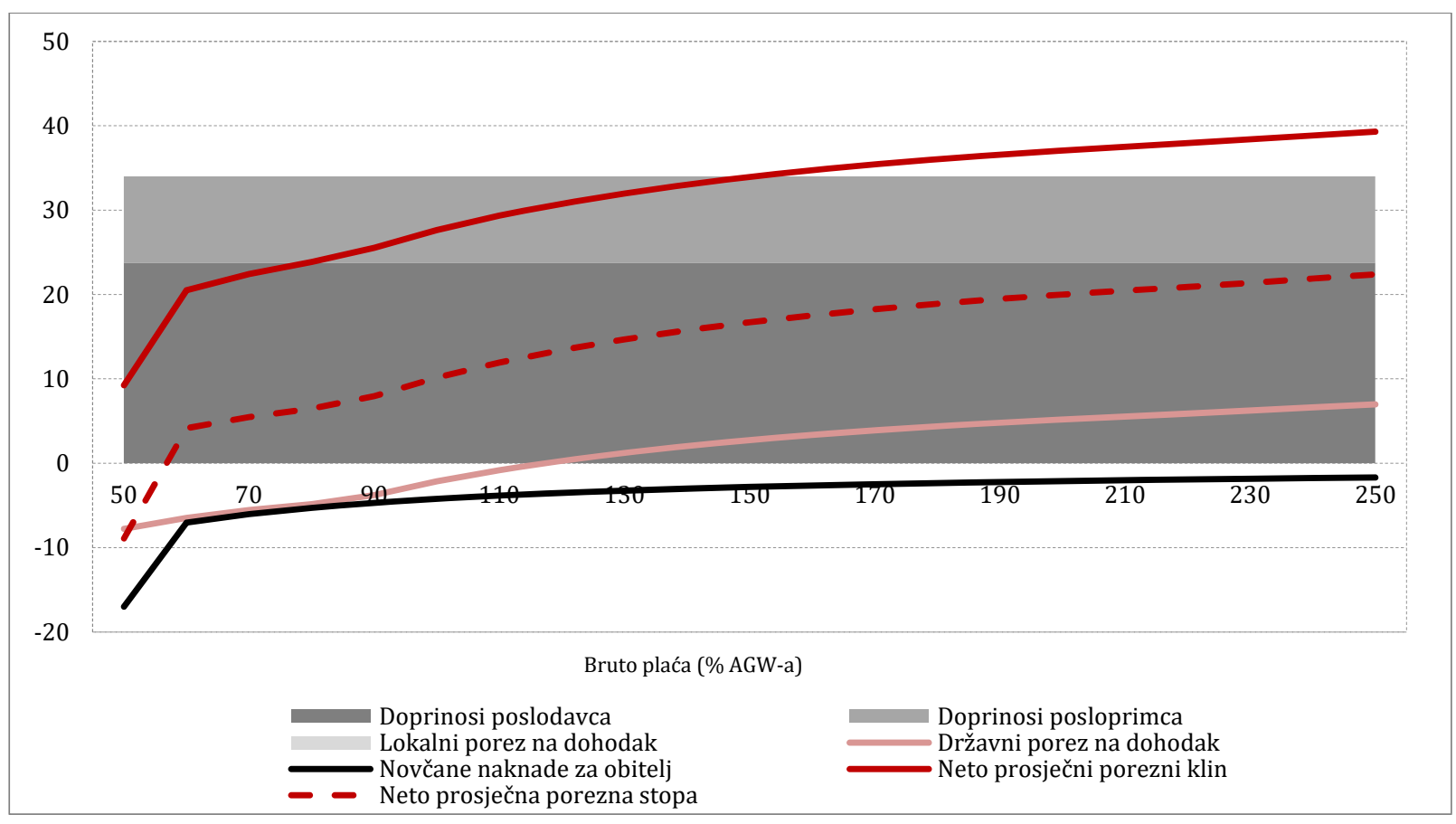

Izvor: autoričini izračuni.

\section{USPOREDBA OPOREZIVANJA PLAĆA PO ZEMLJAMA}

Nakon proučavanja poreznih sustava svake zemlje zasebno, u ovom dijeli slijedi usporedba poreznog opterećenja za različite tipove obitelji i različite razine bruto plaća u svim promatranim zemljama.

Grafikon 21 prikazuje usporedbu neto prosječnog poreznog klina za samca bez djece s bruto plaćom od 100\% AGW-a (1A-100-NC) i za par s dvoje djece, gdje samo jedan supružnik radi i prima bruto plaću od $100 \%$ AGW-a (2A-100/0-2C).

Porezni klin za obje hipotetske jedinice najniži je u Hrvatskoj, a najviši u Belgiji. Samci su u svim zemljama u nepovoljnijem položaju nego obitelji s djecom. U Belgiji porezni klin za samce doseže $55,8 \%$ ukupnih troškova rada. Razlog tome su visoke porezne stope i relativno uski porezni razredi u Belgiji, pri čemu već i samac s prosječnom bruto plaćom ulazi u gornji porezni razred, gdje na dio osnovice plaća porez po stopi od visokih $50 \%$. 
GRAFIKON 21.

Usporedba neto prosječnog poreznog klina za hipotetske jedinice 1A-100-NC i 2A-100/0-2C, u \%

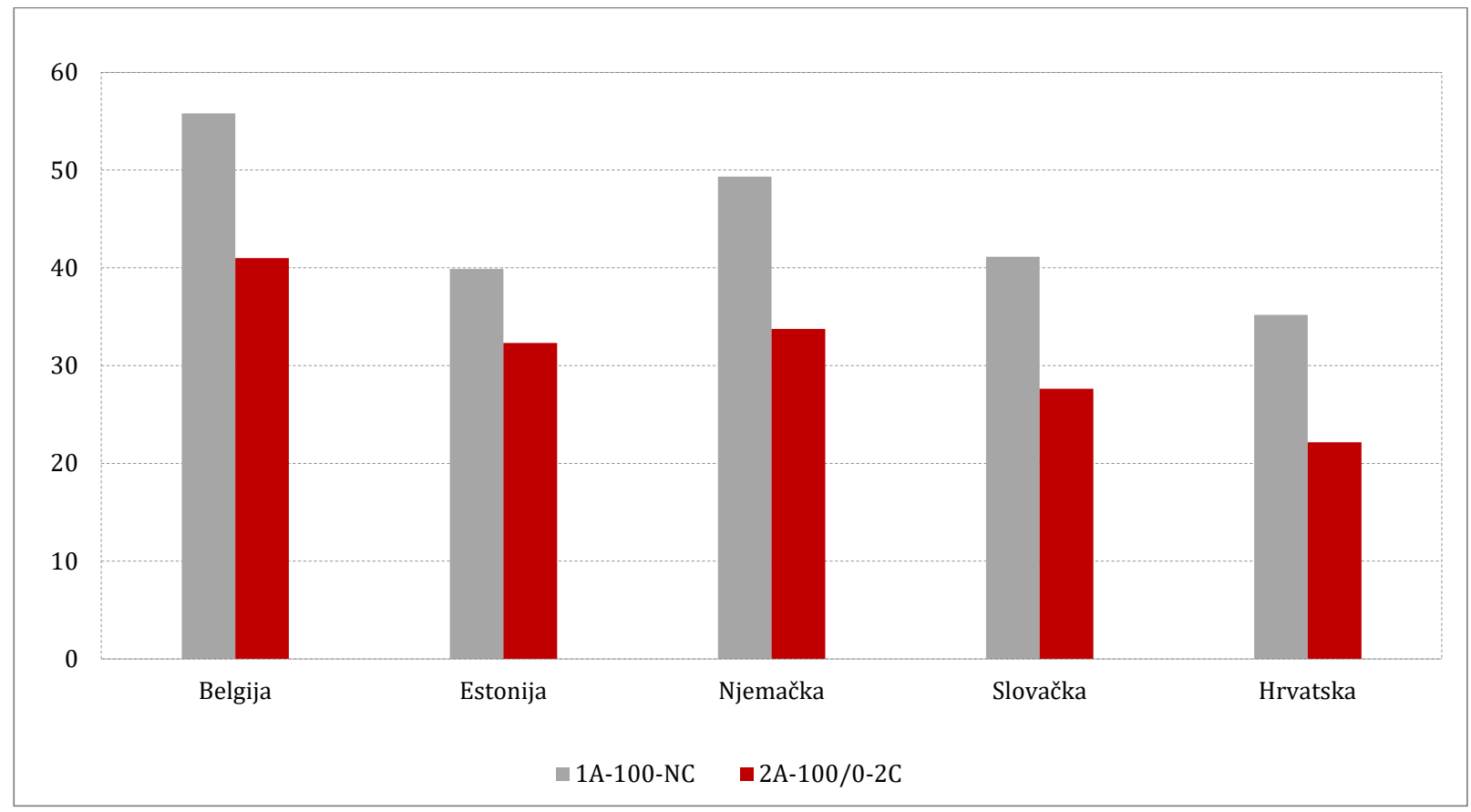

Izvor: autoričini izračuni.

\section{GRAFIKON 22.}

Usporedba neto prosječnog poreznog klina za hipotetske jedinice 1A-167-NC i 2A-100/67-2C, u \%

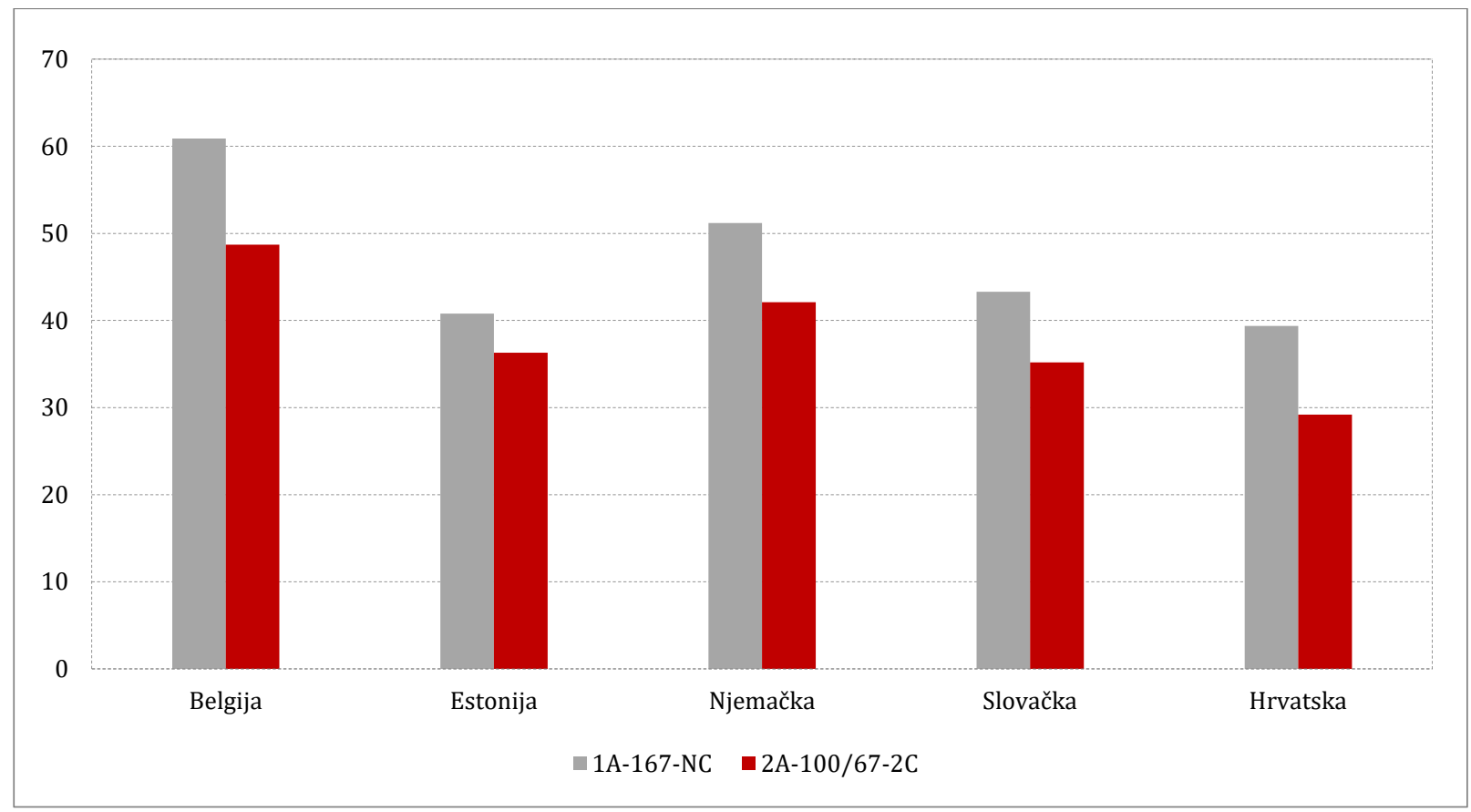

Izvor: autoričini izračuni.

Grafikon 22 prikazuje udio poreznog tereta u ukupnim troškovima rada za samca bez djece koji ostvaruje bruto plaću od 167\% AGW-a (1A-167-NC) te za par s dvoje djece čija ukupna bruto plaća također iznosi $167 \%$ AGW-a, ali je raspoređena tako da jedan supružnik prima $100 \%$, a drugi $67 \%$ AGW-a (2A-100/67-2C). 
Porezni klin za obje hipotetske jedinice najviši je u Belgiji, a najniži u Hrvatskoj. Međutim, postoje sličnosti u razini poreznog opterećenja između Hrvatske, Estonije i Slovačke. Estonija nema porezne razrede, a u Slovačkoj samo izrazito visoki dohodak upada u viši porezni razred te se oporezuje po stopi od 25\%. U Hrvatskoj postoji više poreznih razreda, no ova razina dohotka se ipak oporezuje po relativno niskim stopama od 12 i 25\%. Za razliku od Hrvatske, Estonije i Slovačke, u Njemačkoj i Belgiji su porezne stope veće i zato su primjetne razlike među zemljama. Kao što je već spomenuto, u Belgiji već i obveznici s prosječnim dohotkom ulaze u najviši porezni razred koji se oporezuje stopom od 50\%.

Hipotetska jedinica s djecom (2A-100/67-2C) u svim zemljama ima manji porezni klin od jedinice bez djece (1A-167-NC). Najveća razlika prisutna je u Belgiji (12\%), a najmanja u Estoniji (4,5\%).

Grafikon 23 prikazuje ovisnost poreznog klina o bruto plaći samca bez djece u svih pet promatranih zemalja. Bruto plaća se kreće od 50 do 400\% AGW-a.

Ponovno odskače Belgija, gdje porezni klin za najveću promatranu razinu bruto plaće iznosi 65\%. Pri razini bruto plaće od oko 200\% AGW-a u Hrvatskoj dolazi do prelaska u najviši porezni razred i oporezivanja dijela osnovice stopom od $40 \%$, a prirez dodatno povećava graničnu poreznu stopu. Tako porezni klin u Hrvatskoj prestiže porezni klin u Estoniji, Slovačkoj i Njemačkoj, redom pri razinama bruto plaće od 190, 230 i 330\% AGW-a. Dakle, za relativno visoke plaće porezni klin u Hrvatskoj jedino je niži od belgijskoga.

\section{GRAFIKON 23.}

Usporedba neto prosječnog poreznog klina za samca bez djece, s bruto plaćom u rasponu od 50 do $400 \% A G W-a, u \%$

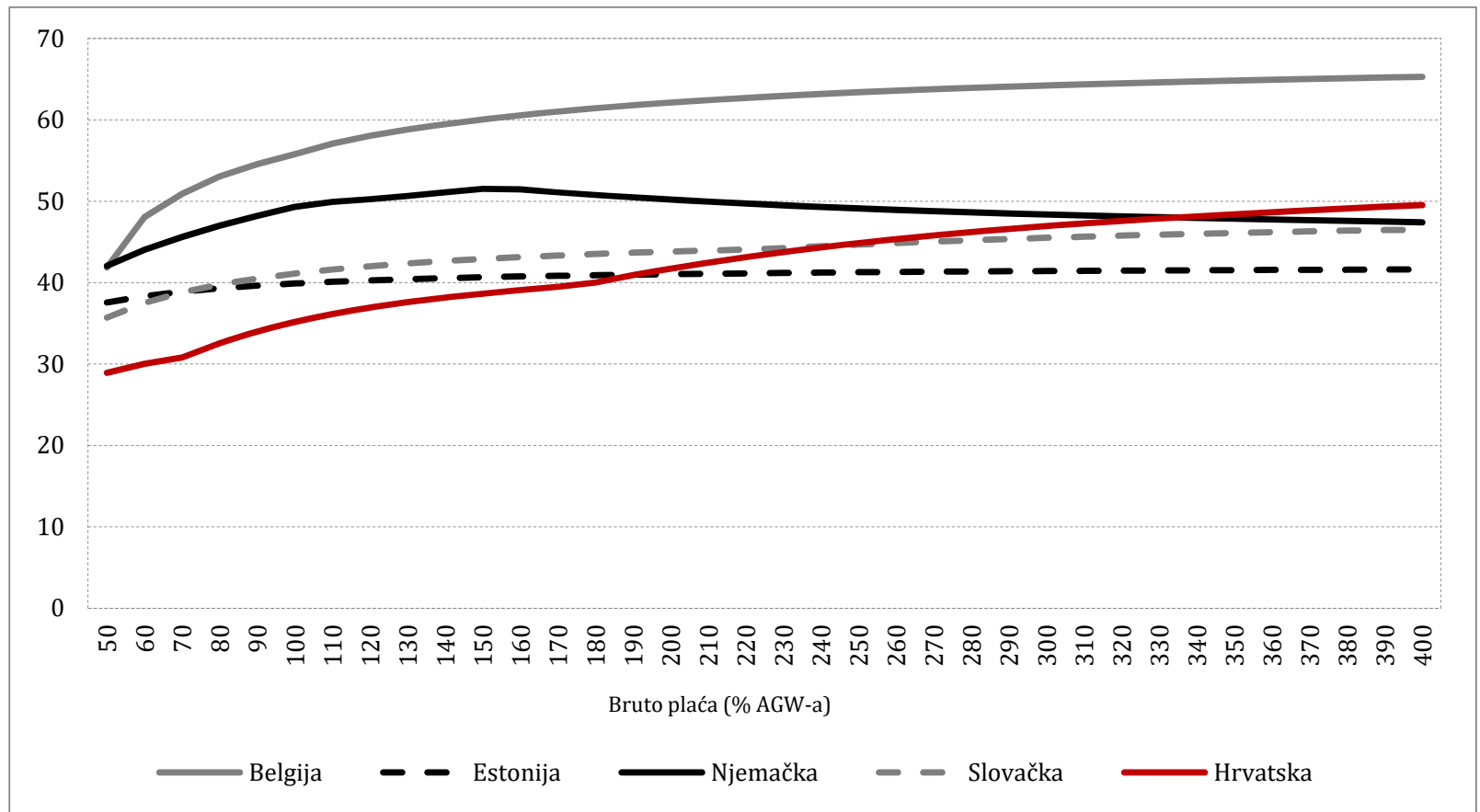

Izvor: autoričini izračuni.

Grafikon 24 prikazuje ovisnost poreznog klina o bruto plaći za hipotetski par s dvoje djece, u kojem jedan supružnik ne radi, a drugi ostvaruje bruto plaću između 50 i 400\% AGW-a. Porezni klin je, osim za niske razine bruto plaće, najveći u Belgiji. Sve zemlje, osim Njemačke (u određenom intervalu), karakterizira progresivnost u oporezivanju dohotka od rada. Ponovno se uočava da je 
za relativno visoke razine dohotka porezni klin u Hrvatskoj najviši od svih promatranih zemalja, izuzev Belgije.

\section{GRAFIKON 24.}

Usporedba neto prosječnog poreznog klina za par s dvoje djece, u kojem jedan supružnik ne radi, a drugi ostvaruje bruto plaću u rasponu od 50 do 400\% AGW-a, u \%

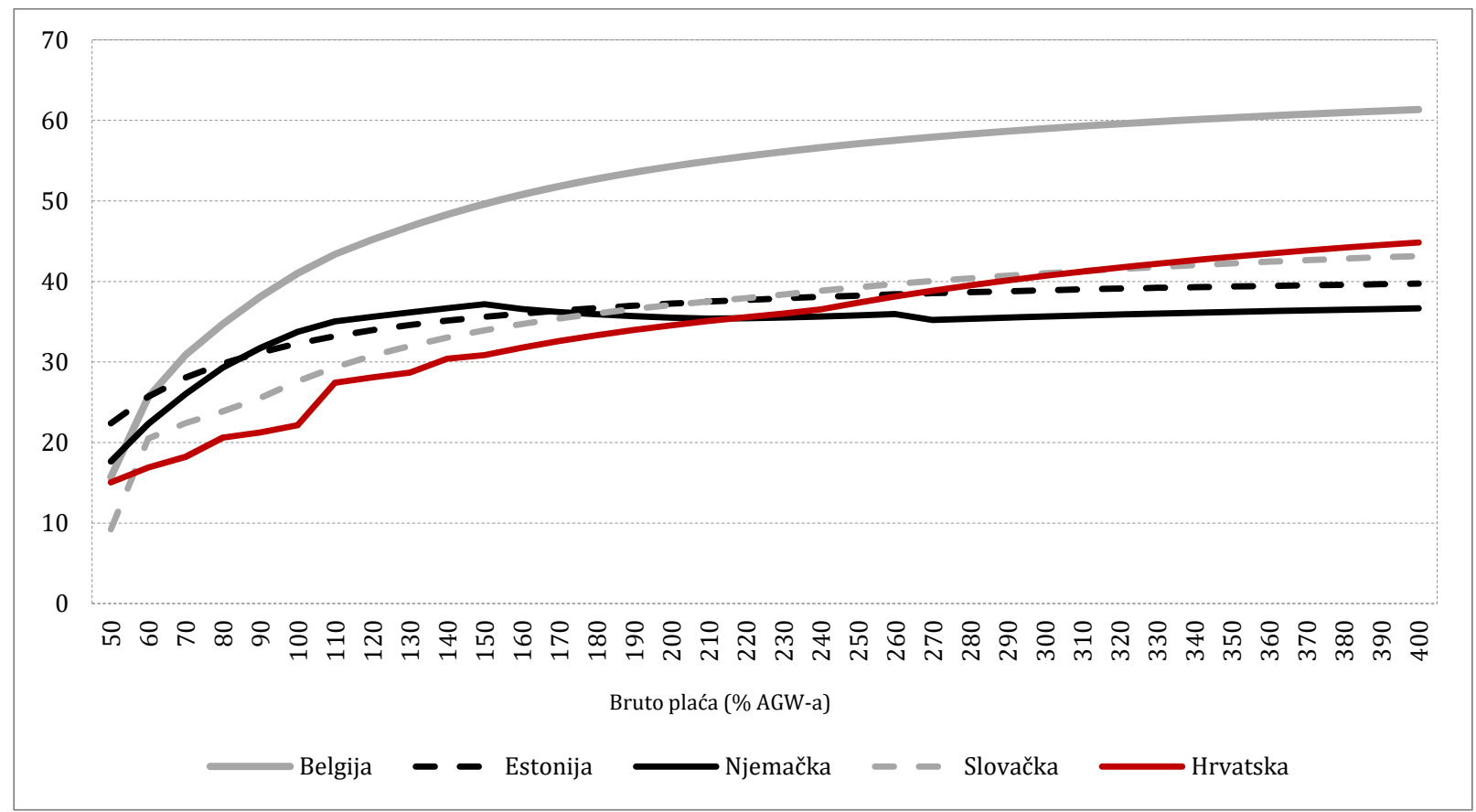

Izvor: autoričini izračuni.

\section{GRAFIKON 25.}

Usporedba neto prosječne porezne stope za samca bez djece, s bruto plaćom u rasponu od 50 do $250 \%$ $A G W-a, u \%$

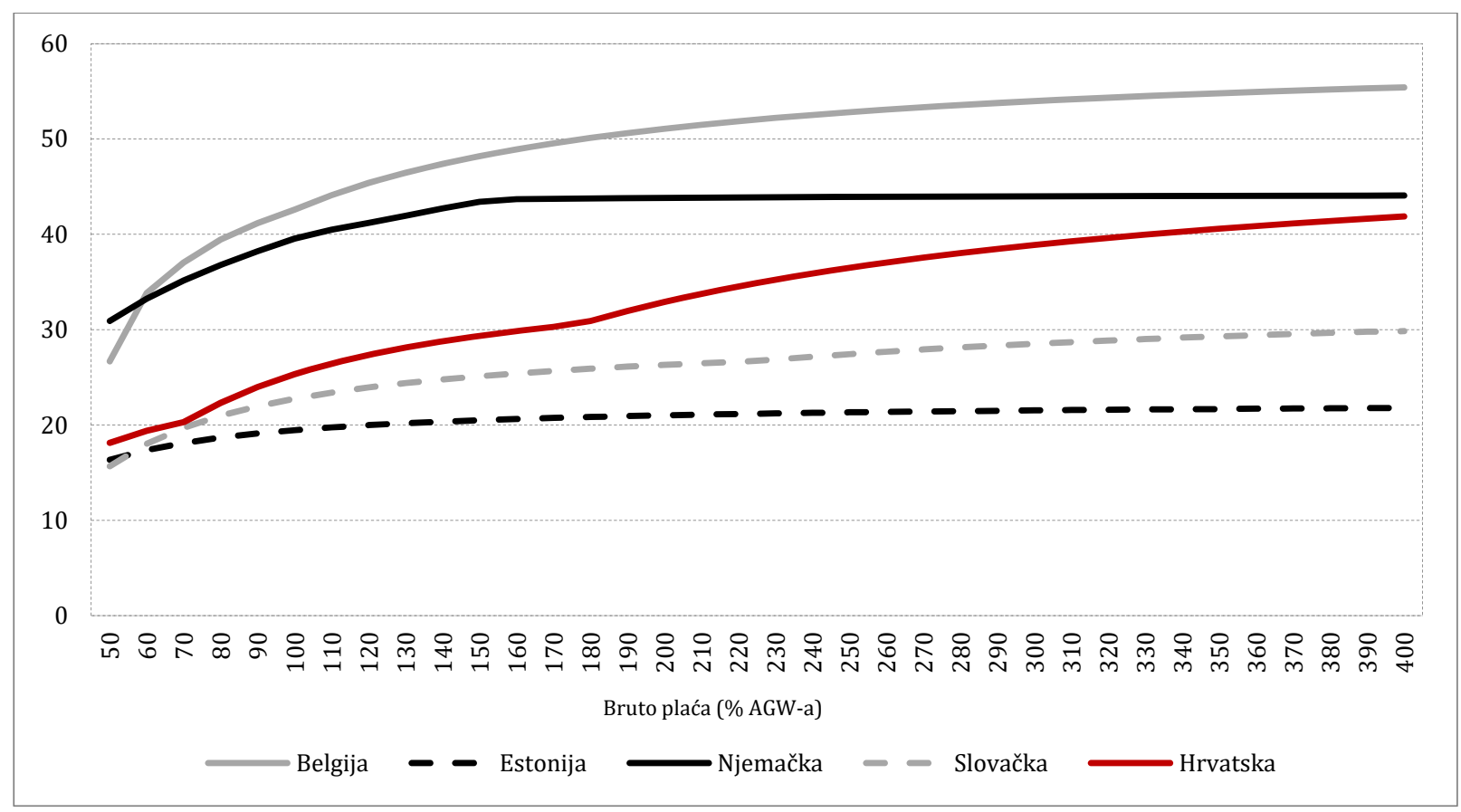

Izvor: autoričini izračuni. 
Grafikon 25 prikazuje neto prosječnu poreznu stopu samca bez djece za sve promatrane zemlje. U Belgiji je ta stopa najveća, osim za niske razine dohotka. Slijedi Njemačka kojoj se za visoke razine dohotka približava Hrvatska. Najviša prosječna porezna stopa, u Belgiji, je dvostruko veća od najniže prosječne porezne stope, u Estoniji.

Grafikon 26 prikazuje prosječnu poreznu stopu za hipotetski par s dvoje djece, u kojem jedan supružnik ne radi, a drugi ostvaruje bruto plaću između 50 i 400\% AGW-a. Može se primijetiti da je linija koja predstavlja Hrvatsku razlomljena. To je posljedica razreda kod doplatka za djecu. ${ }^{2}$ Iznad razine prosječne plaće, prosječna porezna stopa u Hrvatskoj nastavlja rasti, dok se rast njemačke prosječne porezne stope usporava nakon što doprinosi postanu konstantni. Neto prosječna porezna stopa u Belgiji, osim za niske razine dohotka, je najviša. Porezni obveznici u Slovačkoj i Estoniji su u najpovoljnijem položaju. Neto prosječna porezna stopa je negativna za neke zemlje jer novčane naknade premašuju obaveze za porez i doprinose.

\section{GRAFIKON 26.}

Usporedba neto prosječne porezne stope za par s dvoje djece, u kojem jedan supružnik ne radi, a drugi ostvaruje bruto plaću u rasponu od 50 do $250 \%$ AGW-a, u \%

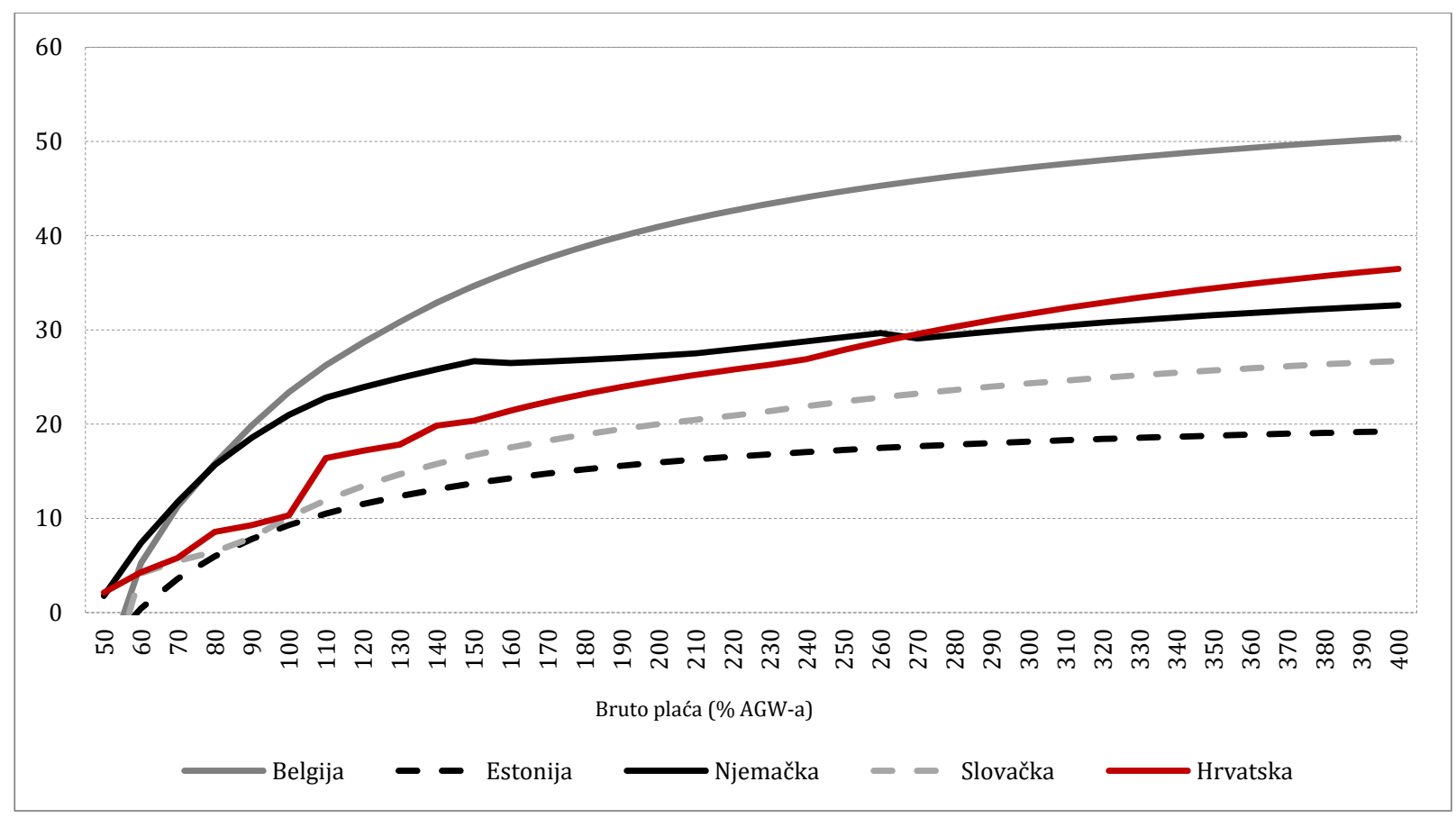

Izvor: autoričini izračuni. 


\section{ZAKLJUČAK}

Predmet istraživanja ovog rada je porezno opterećenje dohotka od rada u pet zemalja Europske unije: Hrvatskoj, Belgiji, Estoniji, Njemačkoj i Slovačkoj. Usporedba neto prosječnih poreznih klinova za samce je pokazala kako je porezni klin za samca bez djece s prosječnom bruto plaćom najmanji u Hrvatskoj, no pri visokim razinama bruto plaće (350\% AGW-a i više), porezni klin u Hrvatskoj je manji samo od belgijskog. Sličan rezultat se dobije i kad se uspoređuje porezni klin para s dvoje djece u kojem samo jedan supružnik radi.

Progresivnost u oporezivanju bi, u teoriji, trebala služiti kao sredstvo kroz koje bi se obaveze za poreze podijelile tako da najviše tereta podnose oni s najvišim mogućnostima. Posljedice toga bi se trebale ogledati u društvu, kroz ujednačenije dohotke poslije oporezivanja i novčanih naknada. U ovom radu doneseni su zaključci o progresivnosti u oporezivanju dohotka pojedinih zemalja. Učinkovitost pojedinih sustava u postizanju podjele poreznih obaveza s ciljem ujednačavanja dohotka je zanimljivo i kompleksno pitanje koje bi vrijedilo i detaljnije istražiti. 


\section{REFERENCE}

1. Blažić, H. i Trošelj, I., 2012. Međunarodna usporedba poreznog opterećenja radne snage: utjecaj nove metodologije na položaj Hrvatske. U: L. Božina, M. Gonan-Božac i D. Učkar, ur. Financije i menadžment u globalnoj ekonomiji. Pula: Sveučilište Jurja Dobrile u Puli, Odjel za ekonomiju i turizam, str.185-204.

2. DZS, 2016. Statistika u nizu: Zaposlenost i plaće [online]. Dostupno na: $<$ http://www.dzs.hr/Hrv_Eng/Pokazatelji/MSI ZAPOSLENOST I PLACE.xlsx>.

3. HNB, 2016. CNB midpoint exchange rate. [online] Dostupno na: <http://www.hnb.hr/en/statistics/statistical-data/central-bank-cnb/cnb-midpoint-exchange-rate>.

4. Čok, M. [et al.], 2013. Taxation of wages in the Alps-Adriatic region. Financial Theory and Practice, 37(3), str. 259-277. doi: 10.3326/fintp.37.3.2

5. Ministarstvo financija, 2015. Oporezivanje primitaka iz radnog odnosa (plaće). [online] Dostupno na: <http://www.porezna-uprava.hr/HR_publikacije/Prirucnici_brosure/Place_161nova.pdf>.

6. OECD, 2014. Taxing Wages 2014. Paris: OECD.

7. Urban, I., 2014. Supports for households with children. Newsletter, br. 88. doi: $10.3326 /$ nle.2014.88

8. Urban, I., 2016. Tax wedge on labour income in Croatia and the European Union. Financial Theory and Practice, 40(2), str. 157-168. doi: 10.3326/fintp.40.2.1

9. Zakon o doplatku za djecu, NN 94/01., 138/06., 107/07., 37/08., 61/11., 112/12., 82/15. [online] Dostupno na: <http://www.zakon.hr/z/475/zakon-o-doplatku-za-djecu>.

10. Zakon o doprinosima, NN 84/08., 152/08., 94/09., 18/11., 22/12., 144/12., 148/13., 41/14., 143/14. [online] Dostupno na: <http://www.zakon.hr/z/365/Zakon-o-doprinosima>. 


\section{DODATAK \\ OPOREZIVANJE DOHOTKA OD RADA U ODABRANIM ZEMLJAMA}

\section{A1. HrVATSKA}

Poslodavci plaćaju tri vrste doprinosa za socijalno osiguranje, a njihova ukupna stopa u 2013. iznosi 15,2\% (tablica A1). Posloprimci plaćaju doprinose u dva stupa mirovinskog osiguranja, čija ukupna stopa iznosi $20 \%$. Prvi stup se temelji na "generacijskoj solidarnosti" i nalazi u okviru središnje države, a drugi stup predstavlja osiguranje na temelju individualne kapitalizirane štednje i uplaćuje se privatnim mirovinskim fondovima. ${ }^{3}$ Najviša osnovica postoji jedino kod doprinosa za prvi stup mirovinsko osiguranje, a u 2013. iznosi 571.608 kuna godišnje.

\section{TABLICA A1.}

Stope doprinosa za socijalno osiguranje (Hrvatska, 2013.)

\begin{tabular}{lcc} 
Doprinos & $\begin{array}{c}\text { Stopa za posloprimca } \\
\text { (\% bruto plaće) }\end{array}$ & $\begin{array}{c}\text { Stopa za poslodavca } \\
\text { (\% bruto plaće) }\end{array}$ \\
\hline Doprinos za prvi stup mirovinskog osiguranja & 15,0 & - \\
\hline Doprinos za drugi stup mirovinskog osiguranja & 5,0 & - \\
\hline Doprinos za zdravstveno osiguranje & - & 13,0 \\
\hline Doprinos za ozljede na radu & - & 0,5 \\
\hline Doprinos za zapošljavanje & - & 1,7 \\
\hline Ukupno & 20,0 & 15,2 \\
\hline
\end{tabular}

Izvor: Zakon o doprinosima (NN 84/08., 152/08., 94/09., 18/11., 22/12., 144/12., 148/13.).

Dohoci oporezivi porezom na dohodak u Hrvatskoj uključuju dohodak od nesamostalnog rada (plaće i mirovine), dohodak od samostalne djelatnosti, dohodak od imovine i imovinskih prava, dohodak od kapitala, dohodak od osiguranja te drugi dohodak (Zakon o porezu na dohodak).

TABLICA A2.

Faktori osobnog odbitka i godišnja svota (Hrvatska, 2013.)

\begin{tabular}{lcc} 
& Faktor osobnog odbitka & Godišnja svota (u kunama) \\
\hline Osnovni osobni odbitak & 1,00 & 26.400 \\
\hline Odrasli uzdržavani član & 0,50 & 13.200 \\
\hline Prvo dijete & 0,50 & 13.200 \\
\hline Drugo dijete & 0,70 & 18.480 \\
\hline Treće dijete & 1,00 & 26.400 \\
\hline Četvrto dijete & 1,40 & 36.960 \\
\hline Peto dijete & 1,90 & 50.160 \\
\hline Za invalidnost & 0,30 & 7.920 \\
\hline Za invalidnost (100\%) & 1,00 & 26.400
\end{tabular}

Napomena: za obveznike koji prebivaju na "posebnim područjima" (u odabranim gradovima i općinama) vrijede uvećani iznosi osobnih odbitaka. U ovom radu se pretpostavlja da osobe ne žive na tim područjima.

Izvor: MFIN-PU (2013.).

\footnotetext{
${ }^{3}$ Drugi stup mirovinskog osiguranja ne ulazi u okvir opće države pa se sukladno Taxing Wages metodologiji ne uzima u obzir pri izračunu pokazatelja poreznog opterećenja. Za detalje vidjeti Urban (2016.).
} 
Iz oporezivog dohotka su isključeni doprinosi posloprimca za oba stupa mirovinskog osiguranja. Svaki obveznik ostvaruje pravo na osnovni osobni odbitak, a za uzdržavanu djecu i odrasle članove obitelji ostvaruje se dodatni osobni odbitak (tablica A2). Supružnici se oporezuju zasebno. Ako oba bračna druga ostvaruju dohodak i uzdržavaju članove uže obitelji, postoje dvije opcije: dodatni osobni odbitak za djecu se dijeli na jednake dijelove ili se može utvrditi drugačija raspodjela. U ovom radu pretpostavlja se da osobni odbitak koristi supružnik s većim dohotkom.

U 2013. su u Hrvatskoj postojala tri porezna razreda (tablica A3) te lokalni prirez porezu na dohodak po stopama od 0 do $18 \%$. U ovom radu koristi se stopa prireza od $12 \%$.

\section{TABLICA A3.}

Porezni razredi i marginalne stope (Hrvatska, 2013.)

Godišnja porezna osnovica Stopa (u \%)

\begin{tabular}{ll}
\hline Do 26.400 kuna & 12 \\
\hline Od 26.400 do 105.600 kuna & 25 \\
\hline Iznad 105.600 kuna & 40
\end{tabular}

Izvor: MFIN-PU (2013.).

Novčane naknade primaju obitelji s djecom u obliku doplatka za djecu čija visina ovisi o neto dohotku (bruto dohodak umanjen za doprinose za mirovinsko osiguranje te porez i prirez) po članu kućanstva. Dohodovne razrede i iznose prikazuje tablica A4.

\section{TABLICA A4.}

Raspored dodjeljivanja doplatka za djecu (Hrvatska, 2013.)

Neto dohodak po članu obitelji (godišnje, u kunama)

\begin{tabular}{lr}
\hline $0-6.518$ & 3.592 \\
\hline $6.518-13.434$ & 2.993 \\
\hline $13.434-19.956$ & 2.395 \\
\hline 19.956 & 0
\end{tabular}

Iznos doplatka po djetetu (godišnje, u kunama)

Izvor: Zakon o doplatku za djecu. 


\section{A2. BELGIJA}

Supružnici se oporezuju pojedinačno. U slučaju da dohodak jednog od supružnika ne prelazi 30\% zajedničkog dohotka, određeni iznos se može pribrojiti dohotku tog supružnika. Iznos koji se pribraja je ograničen iznosom od 30\% zajedničkog neto dohotka umanjenog za dohodak supružnika na kojeg se iznos prenosi. Taj iznos ne smije biti veći od 10.090 eura. Supružnici prijavu poreza na dohodak podnose zajedno.

Posloprimci plaćaju doprinose u iznosu 13,07\% bruto plaće (tablica A5) te mogu iskoristiti pravo na umanjenje obaveze za doprinose ovisno o razini bruto plaće. Kroz 2013. raspored umanjenja se mijenjao, a za potrebe izračuna u ovom radu pronađena je ponderirana aritmetička sredina te su korišteni podaci prikazani u tablici A6.

\section{TABLICA A5.}

Doprinosi posloprimaca u postotku bruto plaće (Belgija, 2013.)

\section{Doprinosi posloprimca}

Doprinos za zapošljavanje

Osiguranje za ozljedu na radu

Zdravstveno osiguranje

Mirovinsko osiguranje

Ukupno

Izvor: OECD (2014.).

\section{TABLICA A6.}

Ponderirana aritmetička sredina rasporeda za umanjenje obaveze za doprinose posloprimaca, u eurima (Belgija, 2013.)

Godišnja bruto plaća (S)

\begin{tabular}{lc}
\hline $0<\mathrm{S}<18.021,84$ & 2.181 \\
\hline $18.021,84<\mathrm{S}<28.624,92$ & $\operatorname{Min}\left(2.181,\left(2.181-0,2057^{*}(\mathrm{~S}-18.021,84)\right)\right.$ \\
\hline $28.624,92<\mathrm{S}$ & 0 \\
\hline
\end{tabular}

Izvor: OECD (2014.).

Posloprimci imaju pravo na standardnu olakšicu za troškove vezane uz posao. Raspored dodjeljivanja je prikazan u tablici A7.

\section{TABLICA A7.}

Olakšice na temelju poslovnih troškova u postotku bruto dohotka umanjene za doprinose za socijalna osiguranja koje plaća zaposlenik (Belgija, 2013.)

\begin{tabular}{lc} 
Bruto dohodak - doprinosi $=$ B (u eurima) & Stopa $(\mathbf{u}$ \%) \\
\hline $\mathrm{B}<5.650$ & 28,70 \\
\hline $5.650<\mathrm{B}<11.220$ & 10 \\
\hline $11.220<\mathrm{B}<18.670$ & 5 \\
\hline $18.670<\mathrm{B}$ & 3
\end{tabular}

Izvor: OECD (2014.). 
Svi zaposlenici su obveznici plaćanja posebnog doprinosa za socijalno osiguranje, ovisno o razini plaće, po rasporedu koji prikazuje tablica A8.

\section{TABLICA A8.}

Raspored plaćanja posebnog doprinosa za socijalno osiguranje (Belgija, 2013.)

\begin{tabular}{lcc}
$\begin{array}{l}\text { Oporezivi dohodak } \\
\text { (u eurima) }\end{array}$ & $\begin{array}{c}\text { Iznos na donjoj granici } \\
(\mathbf{u} \in \mathbf{f}\end{array}$ & $\begin{array}{c}\text { \% od oporezivog dohotka } \\
\text { umanjenog za iznos donje }\end{array}$ \\
\hline $0-18.592,02$ & 0 & 0 \\
\hline $18.592,02-21.070,96$ & 0 & 9 \\
\hline $21.070,96-60.161,85$ & 223,10 & 1,30 \\
\hline $60.161,85$ i više & 731,29 & 0 \\
\hline
\end{tabular}

Izvor: OECD (2014.).

Poslodavci plaćaju doprinose u iznosu $34,67 \%$ bruto plaće. Pregled doprinosa prikazan je u tablici A9. Poslodavci imaju pravo na umanjenje ukupnih doprinosa za $1 \%$. To ne utječe na zaposlenike, već onda ukupni doprinosi koje plaća poslodavac iznose 33,67\% ukupne plaće.

\section{TABLICA A9.}

Doprinosi poslodavca na bruto plaću zaposlenika (Belgija, 2013.)

\begin{tabular}{lc} 
Naziv doprinosa & Postotak bruto plaće \\
\hline Zapošljavanje & 3,16 \\
\hline Osiguranje za iznenadne zdravstvene probleme & 2,35 \\
\hline Zdravstveno osiguranje & 3,80 \\
\hline Usluge zapošljavanja & 0,05 \\
\hline Doplatak za obitelji & 7,00 \\
\hline Mirovinsko osiguranje & 8,86 \\
\hline Dječje osiguranje & 0,05 \\
\hline Bolest nastala zbog posla & 1,01 \\
\hline Ozljeda na radu & 0,32 \\
\hline Obrazovanje radnika & 0,05 \\
\hline Zatvaranje tvrtke & 0,43 \\
\hline Ograničavanje plaće & 7,59 \\
\hline Ukupno & 34,67
\end{tabular}

Izvor: OECD (2014.).

Kroz 2013. raspored umanjenja se mijenjao, a za potrebe izračuna u ovom radu pronađena je ponderirana aritmetička sredina te su korišteni podaci prikazani u tablici A10.

\section{TABLICA A10.}

Ponderirana aritmetička sredina rasporeda umanjenja obaveze za doprinose poslodavca (u eurima) (Belgija, 2013.)

\begin{tabular}{lcc} 
Godišnji bruto dohodak (S) & Fiksni iznos & Varijabilni iznos \\
\hline $0-22.627,9$ & $1.757,50$ & $0,162^{*}(22.627,79-\mathrm{S})$ \\
\hline $22.627,9-53.314,20$ & $1.757,50$ & 0 \\
\hline $53.314,20$ i više & $1.757,50$ & $0,06^{*}(\mathrm{~S}-53.314,20)$ \\
\hline
\end{tabular}


Posloprimčevi doprinosi za socijalna osiguranja (tablica A7) te poslovni troškovi (tablica A9) se koriste za umanjenje porezne osnovice. Rezultat, oporezivi dohodak, se oporezuje ovisno o poreznom razredu u kojem se nalazi. Porezne razrede i stope prikazuje tablica A11.

\section{TABLICA A11.}

Porezni razredi i marginalne porezne stope (Belgija, 2013.)

Oporezivi dohodak (u eurima)

Marginalna stopa (u \%)

\begin{tabular}{ll}
\hline $0-8.590$ & 25 \\
\hline $8.590-12.220$ & 30 \\
\hline $12.220-20.370$ & 40 \\
\hline $20.370-37.330$ & 45 \\
\hline 37.330 i više & 50
\end{tabular}

Izvor: OECD (2014.).

Porezna obaveza može se umanjiti, a osnove za umanjenje su sljedeće:

(a) Osnovna osnovica na temelju oporezivog dohotka, S. Uvjete i iznose prikazuje tablica A12.

(b) Osnovica na temelju uzdržavane djece (tablica A13).

(c) Posebne osnovice. Koristit će se samo ona koja se dobije ako je osoba samohrani roditelj, a ona iznosi 1.490 eura.

TABLICA A12.

Umanjenje porezne osnovice (u eurima) (Belgija, 2013.)

Oporezivi dohodak $S$

Fiksni iznos

Varijabilni iznos

$\begin{array}{lcc}0-25.990 & 7.270 & 0 \\ 25.990-26.270 & 6.990 & 26.270-\mathrm{S} \\ 26.270 \text { i više } & 6.990 & 0\end{array}$

Izvor: OECD (2014.).

\section{TABLICA A13.}

Osnovica za umanjenje poreza koja se dodjeljuje za djecu (Belgija, 2013.)

Broj djece Iznos osnovice (u eurima)

\begin{tabular}{lr}
\hline 1 & 1.490 \\
\hline 2 & 3.820 \\
\hline 3 & 8.570 \\
\hline 4 & 13.860 \\
\hline
\end{tabular}

Izvor: OECD (2014.).

Obaveza za lokalne poreze u Belgiji se računa kao postotak obaveze za porez na dohodak prije nego se ta obaveza umanji za posebne porezne odbitke koji se dobiju na temelju niskog dohotka ili na temelju troškova koji su nastali u svrhu uštede energije. Stopu lokalnog poreza određuju općine, pri čemu ne postoji gornja granica. Prosječna stopa za cijelu Belgiju iznosi 7,4\%.

Univerzalne novčane naknade postoje ako posloprimac ima djecu. Za izračune u ovom radu vrijedit će pretpostavka da posloprimac ima dvoje djece ili nema djece. U slučaju da ima dvoje djece, pretpostavlja se da je jedno dijete staro između sedam i deset godina, a drugo između jedanaest i dvanaest godina. Tada ukupne novčane naknade iznose $1.330,71$ eura $+2.462,94$ eura $=$ 3.793,65 eura godišnje. 


\section{A3. EstoniJA}

Porezna jedinica je obitelj. Posloprimci i poslodavci plaćaju doprinose koji su prikazani u tablici A14. Ukupna obaveza posloprimca za doprinose iznosi $2 \%$ bruto plaće, dok ukupna obaveza poslodavca za doprinose iznosi $34 \%$ bruto plaće iz čega je vidljivo da veći dio tereta za doprinose pada na poslodavca.

\section{TABLICA A14.}

Raspored obaveza za doprinose (Estonija, 2013.)

\begin{tabular}{lcc} 
Naziv doprinosa & Posloprimac (\% bruto plaće) & Poslodavac (\% bruto plaće) \\
\hline Zapošljavanje & 2 & 1 \\
\hline Zdravstveno osiguranje & 0 & 13 \\
\hline Mirovinsko osiguranje & 0 & 20 \\
\hline
\end{tabular}

Izvor: OECD (2014.).

Osnovna olakšica za umanjenje porezne osnovice iznosi 1.728 eura. Kao olakšica priznaju se i uplate doprinosa za zapošljavanje te se posebne olakšice dobiju na temelju uzdržavane djece (tablica A15).

\section{TABLICA A15.}

Osnovica za umanjenje porezne osnovice koja se dodjeljuje za djecu (Estonija, 2013.)

Broj djece

Iznos osnovice (u eurima)

\begin{tabular}{lc}
1 & 0 \\
\hline 2 & 1.728 \\
\hline 3 & 3.456 \\
\hline 4 & 5.184
\end{tabular}

Izvor: OECD (2014.).

U Estoniji postoje i nestandardne porezne olakšice kao što su uplate u privatne mirovinske fondove, osiguranja, kamate na stambene kredite te troškovi obrazovanja. U ovom radu modeli ne uključuju nestandardne porezne olakšice. Važno je napomenuti da postoje i da stvarna situacija odudara od one prikazane modelom.

Dohodak se oporezuje po stopi od $21 \%$. Ne postoje regionalni ili lokalni porezi. Država plaća doplatak za djecu do 16 godina, a ako se djeca školuju, onda do njihove 19. godine. Ovi prihodi nisu oporezivi. Raspored odijeljivanja novčanih naknada prikazan je u tablici A16.

\section{TABLICA A16.}

Novčane naknade u obliku doplatka za djecu (Estonija, 2013.)

Tip beneficije Godišnji iznos (u eurima)

Doplatak (do 16. ili 19. godine)

\begin{tabular}{lr} 
Za prvo i drugo dijete & 230,16 \\
\hline Za treće i svako sljedeće & 690,48 \\
\hline Za dijete samohranog roditelja & 230,16 \\
\hline Za obitelji sa sedam ili više djece & $2.024,88$
\end{tabular}
Izvor: OECD (2014.). 


\section{A4. NJEMAČKA}

Iako je supružnicima pružena opcija da prijavu poreza na dohodak podnose zasebno, za izračune u ovom radu pretpostavit ćemo da prijavu podnose zajedno.

Obveznici plaćanja doprinosa u Njemačkoj su posloprimac i poslodavac. Raspored plaćanja doprinosa prikazan je u tablici A17.

\section{TABLICA A17.}

Raspored obaveza za doprinose (Njemačka, 2013.)

\begin{tabular}{lcc} 
Naziv doprinosa & Posloprimac (\% bruto plaće) & Poslodavac (\% bruto plaće) \\
\hline Zapošljavanje & 1,50 & 1,50 \\
\hline Bolovanje & 8,20 & 7,30 \\
\hline Mirovinsko osiguranje & 9,45 & 9,45 \\
\hline Dugoročna skrb (nema djece) & 1,275 & 1,025 \\
\hline $\begin{array}{l}\text { Dugoročna skrb (ima barem } \\
\text { jedno dijete) }\end{array}$ & 1,025 & 1,025
\end{tabular}

Izvor: OECD (2014.).

Olakšice za uplaćene doprinose za socijalna osiguranja i drugi troškovi nastali zbog namjere osiguranja u budućnosti (npr. životno osiguranje) računaju se prema sljedećim koracima:

1. Svi doprinosi koji su uplaćeni u mirovinske fondove (posloprimčevi i poslodavčevi) se zbroje.

2. Uzima se minimum dobivenog iznosa i iznosa od 20.000 eura.

3. Uzme se određeni postotak od iznosa dobivenog nakon koraka 2. U 2005. je taj postotak iznosio 60\%. Za svaku sljedeću godinu se povećavao za 2\%. U 2013. iznosio je 76\%, a 2025. će doseći $100 \%$.

4. Dobiveni iznos, umanjen za neoporezive doprinose poslodavca, se može iskoristiti kao porezna olakšica.

Doprinosi posloprimca za zdravstveno osiguranje, za koje se pretpostavlja da iznose $96 \%$ ukupnih uplata za zdravstvo i za obavezno osiguranje u slučaju potrebe za dugotrajnom njegom, se mogu iskoristiti kao porezne olakšice. Doprinosi za zapošljavanje i drugi doprinosi se isto mogu iskoristiti kao porezna olakšica, do iznosa od 1.900 eura za samce, tj. 3.800 eura za parove. U njemačkom poreznom sustavu ne postoji porezna olakšica u obliku osnovnog odbitka.

Poslovni troškovi u iznosu od 1.000 eura se smatraju porezno priznatima. Ako se prilože dokazi da je taj iznos prekoračen, cijeli iznos se može iskoristiti kao porezna olakšica. Fiksan iznos od 36/72 eura za samca/bračni par je porezno priznat kao trošak obrade porezne prijave.

Porezni razredi se temelje na sljedećim formulama:

$X=$ oporezivi dohodak

$T=$ obveza za porez

$$
\begin{array}{r}
Y=\frac{X-8130}{10000} \\
Z=\frac{X-13469}{10000} \\
T=0, \text { za } X \leq 8130
\end{array}
$$




$$
\begin{aligned}
& T=(933,70 Y+1400) Y, \text { za } 8131 \leq X \leq 13469 \\
& T=(228,74 Z+2397) Z+1014, \text { za } 13470 \leq X \leq 52881 \\
& T=0,42 X-8196, \text { za } 52882 \leq X \leq 250730 \\
& T=0,45 X-15718, \text { za } 250731 \leq X
\end{aligned}
$$

Koristeći ove formule izračunava se porezna obaveza za samca. Porezna obaveza za par, koji poreznu prijavu podnosi zajedno, se računa tako da se porez na dohodak računa za polovicu zajedničkog oporezivog dohotka. Zatim se dobiveni iznos udvostruči kako bi se dobila porezna obaveza za oboje supružnika.

Postoji i obaveza za tzv. solidarni nadoplatak koja iznosi 5,5\% porezne obaveze, uz izuzetak od 972 eura za samca, odnosno 1.944 eura za parove. Ako porezna obaveza premašuje iznose izuzetka, onda će se solidarni nadoplatak računati kao $20 \%$ razlike između porezne obaveze i granice izuzetka. Porezna obaveza se računa uzimajući u obzir porezne olakšice za djecu. 


\section{A5. SLOVAČKA}

Prilikom oporezivanja plaća u Slovačkoj gleda se svaka osoba zasebno.

Doprinosi za socijalna osiguranja koje uplaćuje posloprimac, ukupno 13,4\% bruto plaće, smatraju se poreznom olakšicom. Posloprimčevi doprinosi su prikazani u tablici A18. Iznosi olakšica su ograničeni s $5^{*} \mathrm{AW}_{\mathrm{t}-2}$ gdje $\mathrm{AW}_{\mathrm{t}-2}$ predstavlja prosječnu plaću od prije dvije godine. Za 2011. iznosila je 9.432 eura godišnje.

\section{TABLICA A18.}

Stope doprinosa zaposlenika (Slovačka, 2013.)

\section{Naziv doprinosa}

Zdravstveno osiguranje

Bolovanje

Mirovinsko

Invalidnost

Zapošljavanje

Izvor: OECD (2014.)
Stopa (u \% bruto plaće)

4

1,40

4

3

1

Poslodavci plaćaju doprinose u iznosu 35,2\% bruto plaće. Od 2005. godine, dio doprinosa za socijalno osiguranje uplaćuje se u privatni mirovinski fond. Budući da su privatni fondovi odvojeni od države, ovi doprinosi neće biti uzeti u obzir pri izračunu prosječne stope poreza. Dakle, u ovom radu ukupni doprinosi poslodavca iznose 31,2\% bruto plaće u 2013. Stope doprinosa poslodavaca prikazane su u tablici A19.

TABLICA A19.

Stope doprinosa poslodavca (Slovačka, 2013.)

Naziv doprinosa

Zdravstveno osiguranje

Bolovanje

Invalidnost

Mirovinsko

Fond

Nezgoda na radu

Nezaposlenost

Rezervni fond

Izvor: OECD (2014.).

Umanjenje poreza za posloprimca uvedeno je 2009. te ovisi o razini posloprimčevih prihoda, a raspored je prikazan u tablici A20. U ovom istraživanju će vrijediti sljedeća konvencija: samo obitelji s nezaposlenim supružnikom imaju pravo na odbitak za supružnika u iznosu 3.735,94 eura.

\section{TABLICA A20.}

Raspored umanjenja poreza za posloprimca (Slovačka, 2013.)

Godišnji prihodi $\mathbf{P}$ (u eurima)

6*337,7<P $<12 * 337,7$

Iznos ETC (u eurima)

$\mathrm{P}>12 * 337,7$ $0,19 *(3.735,94-3.509,76)$

Izvor: OECD (2014.).
Stopa (u \% bruto plaće)

1,40

3

0,80

4,75 
Osnovni osobni odbitak dodjeljuje se po kriterijima koji su prikazani u tablici A21.

TABLICA A21.

Osobni odbitak (Slovačka, 2013.)

Razina dohotka

Iznos olakšice (u eurima)

Bruto dohodak $<19.458$

$19,2 * 3.735,94$

$19.458<$ bruto dohodak

$44,2 * 3.735,94-0,25 *$ (bruto dohodak - socijalni doprinosi)

Bruto dohodak - socijalni doprinosi $>34.401$

0

Izvor: OECD (2014.).

Od 2013. Slovačka ima dva porezna razreda prikazana u tablici A22. Ne postoje porezi na lokalnoj razini.

TABLICA A22.

Porezni razredi i marginalne stope (Slovačka, 2013.)

Godišnji oporezivi dohodak (u eurima)

Stopa (u \%)

0 - 34.401,74

19

$34.401,74$ i više

25

Izvor: OECD (2014.).

Godišnje umanjenje porezne obaveze u 2013. godini iznosilo je 254,64 eura za svako dijete. Ako porezna obaveza postane negativna, a obveznik zarađuje barem 2.026,2 eura godišnje, iznos porezne obaveze država plaća obvezniku. Ovu poreznu olakšicu može iskoristiti samo jedan od supružnika. U ovom radu pretpostavljamo da olakšicu koristi supružnik s većim dohotkom. Raspored umanjenja porezne obveze prikazan je u tablici A23.

TABLICA A23.

Raspored umanjenja porezne obaveze (Slovačka, 2013.)

Broj djece

Iznos osnovice (u eurima)

\begin{tabular}{lr}
\hline 1 & 254,64 \\
\hline 2 & 509,28 \\
\hline 3 & 763,92 \\
\hline 4 & $1.018,56$
\end{tabular}

Izvor: OECD (2014.).

Novčana naknada iznosi 23,10 eura mjesečno za svako dijete. Postoji i pomoć socijalno ugroženim obiteljima koja se isplaćuje u obliku socijalne pomoći. Ako ukupni dohodak obitelji ne prelazi minimalni životni standard izračunat za tu obitelj, onda je obitelj korisnik mjesečne socijalne pomoći po rasporedu prikazanom u tablici A25. Kriteriji za izračun minimalnog životnog standarda su prikazani u tablici A24. 
TABLICA A24.

Minimalni životni standard (u eurima) (Slovačka, 2013.)

Do 30. 6. 2013.

Od 1. 7. 2013.

\begin{tabular}{lrc}
\hline Prva odrasla osoba & 194,58 & 198,09 \\
\hline Druga odrasla osoba & 135,74 & 138,19 \\
\hline Dijete & 88,82 & 90,42 \\
\hline
\end{tabular}

Izvor: OECD (2014.).

TABLICA A26.

Raspored dodjeljivanja socijalne pomoći (Slovačka, 2013.)

Tip obitelji

Samac bez djece

Samac koji ima od jedno do četvero djece

Par koji ima od jedno do četvero djece

Par bez djece

Samac s više od četvero djece

Par s više od četvero djece

Izvor: OECD (2014.).
Mjesečna socijalna pomoć (u eurima)

60,50

115,10

157,60

105,20

168,20

212,30 